\title{
Multi-nutrient, multi-group model of present and future oceanic phytoplankton communities
}

\author{
E. Litchman ${ }^{1,2}$, C. A. Klausmeier ${ }^{2,3}$, J. R. Miller ${ }^{1}$, O. M. Schofield ${ }^{1}$, and P. G. Falkowski ${ }^{1}$ \\ ${ }^{1}$ Institute of Marine and Coastal Sciences, Rutgers University, New Brunswick, NJ 08901, USA \\ ${ }^{2}$ Michigan State University, Kellogg Biological Station, MI 49060, USA \\ ${ }^{3}$ Department of Ecology and Evolutionary Biology, Princeton University, Princeton, NJ 08544, USA
}

Received: 16 January 2006 - Published in Biogeosciences Discuss.: 19 June 2006

Revised: 18 October 2006 - Accepted: 11 November 2006 - Published: 28 November 2006

\begin{abstract}
Phytoplankton community composition profoundly affects patterns of nutrient cycling and the dynamics of marine food webs; therefore predicting present and future phytoplankton community structure is crucial to understand how ocean ecosystems respond to physical forcing and nutrient limitations. We develop a mechanistic model of phytoplankton communities that includes multiple taxonomic groups (diatoms, coccolithophores and prasinophytes), nutrients (nitrate, ammonium, phosphate, silicate and iron), light, and a generalist zooplankton grazer. Each taxonomic group was parameterized based on an extensive literature survey. We test the model at two contrasting sites in the modern ocean, the North Atlantic (North Atlantic Bloom Experiment, NABE) and subarctic North Pacific (ocean station Papa, OSP). The model successfully predicts general patterns of community composition and succession at both sites: In the North Atlantic, the model predicts a spring diatom bloom, followed by coccolithophore and prasinophyte blooms later in the season. In the North Pacific, the model reproduces the low chlorophyll community dominated by prasinophytes and coccolithophores, with low total biomass variability and high nutrient concentrations throughout the year. Sensitivity analysis revealed that the identity of the most sensitive parameters and the range of acceptable parameters differed between the two sites. We then use the model to predict community reorganization under different global change scenarios: a later onset and extended duration of stratification, with shallower mixed layer depths due to increased greenhouse gas concentrations; increase in deep water nitrogen; decrease in deep water phosphorus and increase or decrease in iron concentration. To estimate uncertainty in our predictions, we used a Monte Carlo sampling of the parameter space where future scenarios were run using parameter combinations that produced acceptable modern day outcomes and the robust-
\end{abstract}

Correspondence to: E. Litchman

(litchman@msu.edu) ness of the predictions was determined. Change in the onset and duration of stratification altered the timing and the magnitude of the spring diatom bloom in the North Atlantic and increased total phytoplankton and zooplankton biomass in the North Pacific. Changes in nutrient concentrations in some cases changed dominance patterns of major groups, as well as total chlorophyll and zooplankton biomass. Based on these scenarios, our model suggests that global environmental change will inevitably alter phytoplankton community structure and potentially impact global biogeochemical cycles.

\section{Introduction}

Although they account for less than $1 \%$ of the photosynthetic biomass on Earth, oceanic phytoplankton are responsible for upwards of $45 \%$ of global net primary production (Field et al., 1998). The fate of net primary production in the oceans is, however, critically dependent on community composition (Doney et al., 2002; Falkowski et al., 2003). For example, phytoplankton communities dominated by diatoms are associated with significantly higher carbon export production than flagellate-dominated communities (Dugdale and Wilkerson, 1998; Smetacek, 1999). Coccolithophorids influence alkalinity, the production of calcite and dimethyl sulfide (DMS) and ocean albedo (Balch et al., 1992; Iglesias-Rodriguez et al., 2002; Holligan and Robertson, 1996; Tyrrell et al., 1999). Understanding the factors that determine the distribution of key phytoplankton groups and their patterns of succession is a fundamentally important but elusive goal in marine ecology.

In this paper we develop a mechanistic model of phytoplankton community structure and first apply it to two characteristic and biogeochemically important regions of the open ocean (the North Atlantic and North Pacific) to describe patterns of seasonal succession in the modern ocean. Our

Published by Copernicus GmbH on behalf of the European Geosciences Union. 
model aims to capture general patterns of seasonal cycles in phytoplankton and apply it to contrasting regions of the global ocean, similarly to the models of Evans and Parslow (1985) and Fasham et al. (1990). We are interested in the long-term behavior of the model when the effects of initial conditions fade away. By examining the steady state predictions, we can explore the long-term shifts in the community resulting from human impacts. While Evans and Parslow (1985) considered seasonal cycles of phytoplankton as a whole, we develop a model to resolve seasonal phytoplankton dynamics at the level of functional groups. Functional groups in phytoplankton are defined as groups of "organisms related through common biogeochemical processes" and are not necessarily phylogenetically related (Iglesias-Rodríguez et al., 2002). However, some of the major taxonomic groups of marine phytoplankton represent distinctly different functional groups (e.g., diatoms as a major silicifying group and coccolithophores as a major calcifying group). Here we explicitly consider the following major taxonomic groups of eukaryotic phytoplankton: diatoms, coccolithophores and prasinophytes. Each group is parameterized based on an extensive compilation of the experimental data on nutrient uptake and growth kinetics, allowing us to meaningfully constrain key model parameters. To obtain a greater taxonomic resolution one must consider multiple nutrients (two forms of inorganic nitrogen, inorganic phosphorus, silica and iron). This allows us to adequately separate controls for different functional groups as the groups appear to be differentiated in their competitive abilities for these nutrients.

After testing the model against modern data, we use it to explore how phytoplankton community structure and patterns of seasonal succession may shift in response to global change. We have two main goals: (1) to identify and model potential mechanisms of the community changes in the contemporary ocean, and (2) to examine how potential changes in ocean mixing and nutrient availability potentially influence phytoplankton community composition over the next century. In addressing these goals, we ask whether a relatively simple model can recreate general patterns in phytoplankton distribution, seasonal succession in the modern ocean. If so, what are the inferred mechanisms responsible for shifts in community composition?

Because our primary goal is to describe phytoplankton community dynamics, we model multiple functional groups explicitly and include groups that are not often represented in models (but see Gregg et al., 2003), i.e., the green flagellate class of prasinophytes. Recent studies indicate that prasinophytes are an important component of eukaryotic picoplankton (van der Staay et al., 2001) and nanoplankton (Rappé et al., 1998) and can contribute significantly to cell numbers and production in various parts of the world ocean (Boyd and Harrison, 1999). Moreover, chlorophytes and prasinophytes are thought to have been dominant phytoplankton in the Palaeozoic ocean (Quigg et al., 2003), hence modeling physical and ecological controls of prasinophytes may help provide an understanding of the factors leading to the success of these organisms during the first half of the Phanaerozoic (Falkowski et al., 2004).

Models that include more than one taxonomic group often divide phytoplankton into diatoms and small algae (e.g., flagellates; Moore et al., 2002). However, small algae are comprised of groups with very different biogeochemical imprints, e.g., coccolithophores versus non-calcifying small algae. Therefore, it is highly relevant to develop models with better taxonomic resolution where more groups are parameterized explicitly. An explicit consideration of multiple functional groups of phytoplankton may also help improve the general model performance (Bissett et al., 1999). The importance of including more major functional/taxonomic groups in the phytoplankton models is even greater when global change scenarios are considered; groups that are not abundant in the present ocean may rise to prominence in the future ocean due to global change.

\section{Materials and methods}

\subsection{Model formulation and parameterization}

The model follows three functional groups of eukaryotic phytoplankton: diatoms, coccolithophoresand green flagellates or prasinophytes (we will use "green algae" and "prasinophytes" interchangeably throughout). We do not include nitrogen fixers because the model is presently applied to high latitudes where nitrogen fixation is not significant due to low temperature (Staal et al., 2003). We also do not include dinoflagellates in the model as in all preliminary runs dinoflagellates were competitively excluded both in current and future ocean scenarios. Our data analysis indicates that dinoflagellates are poor competitors for inorganic nutrients (see below) and even low grazer preference of dinoflagellates did not result in their persistence. Mixotrophy likely contributes to the success of dinoflagellates in the ocean (Smayda, 1997) but is not included in our model. As autotrophic dinoflagellates are not abundant at NABE (Joint et al., 1993) and OSP, we did not attempt to refine the model by including organic nutrient utilization by dinoflagellates. Consequently, to reduce simulation times, we did not include dinoflagellates in subsequent runs. We, however, include physiological parameter values for this functional group and discuss its potential competitive abilities for inorganic nutrients for future reference.

The biomass of each group increases through growth and decreases by density-independent mortality (basal metabolic losses and sinking), by dilution due to deepening of the mixed layer, and grazing (Eq. 1). The model variables and parameters are given in Tables 1-3. The growth of each group can be limited by nitrogen $(\mathrm{N})$ (nitrate and ammonium), phosphorus $(\mathrm{P})$, silica $(\mathrm{Si})$ (diatoms only), iron $(\mathrm{Fe})$ and light (I) (Eq. 2). For N, P and Fe we use a model 
formulation where growth depends on the internal concentration of a nutrient (Droop, 1973). This formulation allows us to track changing particulate nutrient ratios that determine patterns of nutrient export and is more realistic than the Monod model in describing algal physiology and nutrient dynamics (Grover, 1991; Klausmeier et al., 2004). This formulation also allows better parameterization as there are multiple studies where Droop parameters are measured. Sidependent growth (for diatoms only) is described by the Monod formulation where growth depends on the external $\mathrm{Si}$ concentration. We explicitly include the dependence of growth on $\mathrm{Fe}$, in addition to $\mathrm{N}, \mathrm{P}$ and $\mathrm{Si}$, as $\mathrm{Fe}$ is an important limiting nutrient in the subarctic North Pacific and may control phytoplankton, especially diatom, growth (Longhurst, 1998; Boyd and Harrison, 1999; Tsuda et al., 2003) and is also relevant for future scenarios. Field studies demonstrate that a large portion of primary production at OSP is dependent on ammonium (Harrison et al., 1999), and therefore, we included that $\mathrm{N}$ source in the model. Light-dependent growth is described as a saturating function of irradiance and includes exponential light gradient and depth-dependent selfshading according to Huisman and Weissing (1994). Growth (biomass) limitation occurs according to Liebig's Law of the minimum, among all resources.

We use Evans and Parlsow's (1985) formulation to describe the effects of changes in ocean mixed-layer depth on nutrient concentration and the phytoplankton and zooplankton densities. With increasing mixed layer depth, $z_{\text {mix }}$, nutrients are entrained into the water column which increases their concentration. Phytoplankton and zooplankton densities become diluted as the mixed layer deepens. Conversely, zooplankton become more concentrated as the mixed-layer depth decreases (Evans and Parslow, 1985).

$h^{+}=\max (h(t), 0)$

where $h(t)=\frac{d z_{\operatorname{mix}}}{d t}$

$\frac{d B_{i}}{d t}=\left(\mu_{i}-m_{i}-\frac{a h^{+}}{z_{m}}-g \frac{c_{i} B_{i}}{k_{z} \sum_{j=1}^{n} c_{j} B_{j}+\sum_{j=1}^{n} c_{j} B_{j}^{2}}\right) B_{i}$

where

$\mu_{i}=\mu_{\max , i} \min \left[\begin{array}{l}\left(1-\frac{Q_{\min , i}^{N}}{Q_{i}^{N}}\right),\left(1-\frac{Q_{\min , i}^{P}}{Q_{i}^{P}}\right),\left(1-\frac{Q_{\min , i}^{\mathrm{Fe}}}{Q_{i}^{\mathrm{Fe}}}\right), \frac{\mathrm{Si}}{k_{i}^{\mathrm{Si}}+\mathrm{Si}}, \\ \frac{1}{\sum_{i=1}^{n} a_{i} B_{i}+a_{b g}} \frac{1}{z_{\mathrm{mix}}} \log \left[\frac{I_{i n}+k_{i}^{I}}{I+k_{i}^{I}}\right]\end{array}\right]$

and

$I=I_{i n} e^{-\left(\sum_{i=1}^{n} a_{i} B_{i}+a_{b g}\right) z_{\operatorname{mix}}}$
Table 1. Model variables.

\begin{tabular}{|c|c|c|}
\hline variable & symbol & units \\
\hline Phytoplankton biomass & $B_{i}$ & $\mu \mathrm{mol} \mathrm{C} \mathrm{L}^{-1}$ \\
\hline Cell quota for $\mathrm{N}$ & $Q_{i}^{N}$ & $\mu \mathrm{mol} \mathrm{N}(\mu \mathrm{mol} \mathrm{C})^{-1}$ \\
\hline Cell quota for $\mathrm{P}$ & $Q_{i}^{P}$ & $\mu \mathrm{mol} \mathrm{P}(\mu \mathrm{mol} \mathrm{C})^{-1}$ \\
\hline Cell quota for $\mathrm{Fe}$ & $Q_{i}^{\mathrm{Fe}}$ & $\mathrm{nmol} \mathrm{Fe}(\mu \mathrm{mol} \mathrm{C})^{-1}$ \\
\hline Nitrate concentration & $\mathrm{N}$ & $\mu \mathrm{mol} \mathrm{L}^{-1}$ \\
\hline Ammonium concentration & $\mathrm{NH}_{4}$ & $\mu \mathrm{mol} \mathrm{L}^{-1}$ \\
\hline Phosphorus concentration & $\mathrm{P}$ & $\mu \mathrm{mol} \mathrm{L}^{-1}$ \\
\hline Iron concentration & $\mathrm{Fe}$ & $\mathrm{nmol} \mathrm{L}-1$ \\
\hline Silicate concentration & $\mathrm{Si}$ & $\mu \mathrm{mol} \mathrm{L}^{-1}$ \\
\hline Zooplankton biomass & $Z$ & $\mu \mathrm{mol} \mathrm{C} \mathrm{L}^{-1}$ \\
\hline Depth of mixed layer & $z_{\operatorname{mix}}$ & $\mathrm{m}$ \\
\hline Incoming irradiance & $I_{\text {in }}$ & mol quanta $\mathrm{m}^{-2}$ day $^{-1}$ \\
\hline
\end{tabular}

where $z_{\text {mix }}$ is the mixed-layer depth, $\mu_{i}$ is the phytoplankton growth rate and the other variables are defined in Tables 13. Internal $\mathrm{N}, \mathrm{P}$ and Fe concentrations are modeled according to Droop (1973). They increase due to nutrient uptake and decrease due to dilution by growth (Eqs. 2 and 3). The quota for nitrogen increases via uptake of ammonium and nitrate and the growth depends on the total internal nitrogen concentration. The uptake of nitrate stops when the nitrogen quota reaches the maximum $\left(Q_{\max }\right)$ and is lower in the presence of ammonium (Dortch, 1990) as described in Fasham et al. (1990), following Wroblewski (1977). $Q_{\max }$ for nitrogen for each group is assumed to be 10 -fold its $Q_{\min }$. The uptake of $\mathrm{P}$ and Fe depends on the external concentration only.

$$
\begin{aligned}
& \frac{d Q_{i}^{N}}{d t}=e^{-\Psi N H_{4}} V_{\max , i}^{N} \frac{N}{k_{i}^{N}+N}\left(\frac{Q_{\max , i}^{N}-Q_{i}^{N}}{Q_{\max , i}^{N}-Q_{\min , i}^{N}}\right) \\
& +V_{\max , i}^{\mathrm{NH}_{4}} \frac{\mathrm{NH}_{4}}{k_{i}^{\mathrm{NH}_{4}}+\mathrm{NH}_{4}}-\mu_{i} Q_{i}^{N}
\end{aligned}
$$

$\frac{d Q_{i}^{P}}{d t}=V_{\max , i}^{P} \frac{P}{k_{i}^{P}+P}-\mu_{i}^{P} Q_{i}^{P}$

$\frac{d Q_{i}^{\mathrm{Fe}}}{d t}=V_{\mathrm{max}, i}^{\mathrm{Fe}} \frac{\mathrm{Fe}}{k_{i}^{\mathrm{Fe}}+\mathrm{Fe}}-\mu_{i}^{\mathrm{Fe}} Q_{i}^{F e}$

Zooplankton density increases as a saturating function of phytoplankton biomass, and the grazing depends on the relative zooplankton preferences for different taxonomic groups of phytoplankton $\left(c_{i}\right)$ and changes as a function of the relative abundances of different groups (as in Fasham et al., 1990). Zooplankton density decreases due to 
Table 2. Group-specific model parameters. Values are medians for each group from our data compilation (see Appendix A for reference list), unless noted otherwise. Where known, the 25 th and 75 th quartiles of the parameter distributions from the data compilation are also given. Parameters that were not sufficiently constrained by the literature data and were allowed to vary for a better model fit ("free parameters") are marked with an asterisk.

\begin{tabular}{|c|c|c|c|c|c|}
\hline Parameter & Symbol, units & diatoms & dinoflag. & $\operatorname{coccos}$ & greens \\
\hline Maximum growth rate & $\mu \max$, day $^{-1}$ & $\begin{array}{l}1.47 \\
0.76-1.94\end{array}$ & $\begin{array}{l}0.52 \\
0.47-0.77\end{array}$ & $\begin{array}{l}1.11 \\
0.91-1.20\end{array}$ & $\begin{array}{l}1.45 \\
1.27-1.59\end{array}$ \\
\hline Minimum $\mathrm{N}$ cell quota & $\mathrm{Q}_{\min }^{N}, \mu \mathrm{mol} \mathrm{N}(\mu \mathrm{mol} \mathrm{C})^{-1}$ & $\begin{array}{l}0.067 \\
0.02-0.07\end{array}$ & $\begin{array}{l}0.045 \\
0.04-0.05\end{array}$ & 0.022 & 0.029 \\
\hline Minimum P cell quota & $\mathrm{Q}_{\min }^{P}, \mu \mathrm{mol} \mathrm{P}(\mu \mathrm{mol} \mathrm{C})^{-1}$ & $\begin{array}{l}1.3 \times 10^{-3} \\
1.0 \times 10^{-3}-1.7 \times 10^{-3}\end{array}$ & $\begin{array}{l}2.8 \times 10^{-3} \\
2.0 \times 10^{-3}-3.0 \times 10^{-3}\end{array}$ & $1.4 \times 10^{-3}$ & $2.3 \times 10^{-3}$ \\
\hline Minimum Fe cell quota ${ }^{1}$ & $\mathrm{Q}_{\min }^{\mathrm{Fe}}, \mathrm{nmol} \mathrm{Fe}(\mu \mathrm{mol} \mathrm{C})^{-1}$ & $3.3 \times 10^{-3}$ & $1.9 \times 10^{-3}$ & $7.2 \times 10^{-4}$ & $2.6 \times 10^{-3}$ \\
\hline $\begin{array}{l}\text { Si cell quota } \\
\end{array}$ & $\mathrm{Q}^{S i}, \mu \mathrm{mol} \mathrm{Si}(\mu \mathrm{mol} \mathrm{C})^{-1}$ & 0.3 & 0 & 0 & 0 \\
\hline Maximum nitrate uptake rate & $\mathrm{V}_{\max }^{N}, \mu \operatorname{mol~N}(\mu \text { mol C day })^{-1}$ & $\begin{array}{l}0.55 \\
0.49-0.78\end{array}$ & $\begin{array}{l}0.004 \\
0.003-0.12\end{array}$ & $\begin{array}{l}0.053 \\
0.046-0.070\end{array}$ & $\begin{array}{l}0.155 \\
0.152-0.158\end{array}$ \\
\hline Maximum ammonium uptake rate & $\mathrm{V}_{\max }^{\mathrm{NH} 4}, \mu \mathrm{mol} \mathrm{N}(\mu \mathrm{mol} \mathrm{C} \text { day })^{-1}$ & $\begin{array}{l}0.81 \\
0.48-0.99\end{array}$ & $\begin{array}{l}0.01 \\
0.01-0.07\end{array}$ & 0.31 & $\begin{array}{l}0.13 \\
0.10-0.21\end{array}$ \\
\hline Maximum $P$ uptake rate & $\mathrm{V}_{\max }^{P}, \mu \operatorname{mol} \mathrm{P}(\mu \text { mol C day })^{-1}$ & $\begin{array}{l}0.50 \\
0.32-0.74\end{array}$ & $\begin{array}{l}0.17 \\
0.05-0.40\end{array}$ & 0.23 & 0.56 \\
\hline Maximum Fe uptake rate ${ }^{3}$ & $\mathrm{~V}_{\max }^{\mathrm{Fe}}, \operatorname{nmol~Fe}(\mu \text { mol C day })^{-1}$ & 0.2 & 0.1 & 0.2 & 0.1 \\
\hline Half-saturation constant for nitrate uptake & $\mathrm{k}^{N}, \mu \mathrm{mol} \mathrm{L}^{-1}$ & $\begin{array}{l}1.25 \\
0.93-1.58\end{array}$ & $\begin{array}{l}5.0 \\
2.5-6.3\end{array}$ & $\begin{array}{l}0.2 \\
0.15-0.21\end{array}$ & $\begin{array}{l}3.41 \\
1.94-4.88\end{array}$ \\
\hline $\begin{array}{l}\text { Half-saturation constant } \\
\text { for ammonium uptake }\end{array}$ & $\mathrm{k}^{\mathrm{NH} 4}, \mu \mathrm{mol} \mathrm{L}-1$ & $\begin{array}{l}1.1 \\
0.44-2.10\end{array}$ & $\begin{array}{l}8.38 \\
2.0-18.0\end{array}$ & $\begin{array}{l}0.2 \\
0.15-0.22\end{array}$ & $\begin{array}{l}0.08 \\
0.04-0.18\end{array}$ \\
\hline $\begin{array}{l}\text { Half-saturation constant } \\
\text { for } \mathrm{P} \text { uptake }\end{array}$ & $\mathrm{k}^{P}, \mu \mathrm{mol} \mathrm{L}^{-1}$ & $\begin{array}{l}0.65 \\
0.51-0.92\end{array}$ & $\begin{array}{l}1.39 \\
0.01-3.3\end{array}$ & $\begin{array}{l}0.40 \\
0.36-0.45\end{array}$ & $\begin{array}{l}0.71 \\
0.32-0.74\end{array}$ \\
\hline Half-saturation constant for $\mathrm{Fe}$ uptake ${ }^{3}$ & $\mathrm{k}^{\mathrm{Fe}}, \mathrm{nmol} \mathrm{L}^{-1}$ & 3.3 & 5.0 & 2.0 & 4.0 \\
\hline${ }^{*}$ Half-saturation constant for light-dependent growth ${ }^{4}$ & $\mathrm{k}^{I}$, mol quanta $\mathrm{m}^{-2}$ day $^{-1}$ & 5.0 & 3.46 & 7.78 & 7.78 \\
\hline Half-saturation constant for Si-dependent growth ${ }^{5}$ & $\mathrm{k}^{S i}, \mu \mathrm{mol} \mathrm{L}^{-1}$ & 1.0 & - & - & - \\
\hline Phytoplankton light attenuation ${ }^{6}$ & a, $\mathrm{m}^{2} \mu \mathrm{mol} \mathrm{C}-1$ & $1.8 \times 10^{-4}$ & $1.8 \times 10^{-4}$ & $1.8 \times 10^{-4}$ & $1.8 \times 10^{-4}$ \\
\hline${ }^{*}$ Phytoplankton basal loss rate (includes sinking) ${ }^{4}$ & $\mathrm{~m}$, day $^{-1}$ & 0.16 & 0.05 & 0.16 & 0.16 \\
\hline${ }^{*}$ Grazing preference ${ }^{4}$ & $\mathrm{c}$, dimensionless & 0.8 & 0.8 & 1.0 & 1.0 \\
\hline
\end{tabular}

${ }^{1}$ Calculated from Sunda and Huntsman (1995), except for green algae, ${ }^{2}$ from Hutchins and Bruland (1998) for diatoms, ${ }^{3}$ this study based on Maldonado et al. (2001), ${ }^{4}$ this study, ${ }^{5}$ from Guillard et al. (1973), ${ }^{6}$ converted from Fasham et al. (1990) assuming Redfield ratio between carbon and nitrogen.

density-independent mortality and is affected by the changing mixed layer as described above:

$\frac{d Z}{d t}=\left(c_{z} g \frac{\sum_{i=1}^{n} c_{i} B_{i}^{2}}{k_{z} \sum_{i=1}^{n} c_{i} B_{i}+\sum_{i=1}^{n} c_{i} B_{i}^{2}}-m_{z}-\frac{h}{z_{\operatorname{mix}}}\right) Z$

External nutrient concentrations increase due to mixing from across the thermocline and nutrient entrainment as the mixed layer deepens and decrease due to uptake by phytoplankton.

$$
\begin{gathered}
\frac{d N}{d t}=\left(N_{i n}-N\right)\left(a+\frac{h^{+}}{z_{\operatorname{mix}}}\right)-e^{-\Psi N H_{4}} \sum_{i=1}^{n} V_{\max , i}^{N} \frac{N}{k_{i}^{N}+N} \\
\left(\frac{Q_{\max , i}^{N}-Q_{i}^{N}}{Q_{\max , i}^{N}-Q_{\min , i}^{N}}\right) B_{i}
\end{gathered}
$$$$
\frac{d N H_{4}}{d t}=\left(\mathrm{NH}_{4 i n}-\mathrm{NH}_{4}\right)\left(a+\frac{h^{+}}{z_{\operatorname{mix}}}\right)-\sum_{i=1}^{n} V_{\max , i}^{\mathrm{NH}_{4}}
$$

$$
\begin{gathered}
\frac{\mathrm{NH}_{4}}{k_{i}^{\mathrm{NH}_{4}}+\mathrm{NH}_{4}} B_{i} \\
\frac{d P}{d t}=\left(P_{i n}-P\right)\left(a+\frac{h^{+}}{z_{\text {mix }}}\right)-\sum_{i=1}^{n} V_{\max , i}^{P} \frac{P}{k_{i}^{P}+P} B_{i} \\
\frac{d F e}{d t}=\left(\mathrm{Fe}_{i n}-\mathrm{Fe}\right)\left(a+\frac{h^{+}}{z_{\text {mix }}}\right)-\sum_{i=1}^{n} V_{\max , i}^{F e} \frac{\mathrm{Fe}}{k_{i}^{\mathrm{Fe}}+\mathrm{Fe}} B_{i} \\
\frac{d S i}{d t}=\left(\mathrm{Si}_{i n}-\mathrm{Si}\right)\left(a+\frac{h^{+}}{z_{\text {mix }}}\right)-\sum_{i=1}^{n} Q_{i}^{\mathrm{Si}} B_{i} \mu_{i}
\end{gathered}
$$

\subsubsection{Parameters}

Each phytoplankton group is represented as a single "species", with the values of the nutrient-related parameters averaged over the range of compiled data for each functional group (Table 2). Briefly, data on nutrient uptake and growth from the published laboratory studies of nutrient-limited cultures of species belonging to the major taxonomic groups were collected and the groups-specific median values for 
Table 3. Non group-specific model parameters. Parameters that were not sufficiently constrained by the literature data and were allowed to vary for a better model fit ("free parameters") are marked with an asterisk.

\begin{tabular}{|c|c|c|c|}
\hline Parameter & Symbol, units & Value & Reference \\
\hline Cross thermocline mixing & $\mathrm{a} 1, \mathrm{~m} \mathrm{day}^{-1}$ & 0.1 & Fasham and Evans (2000) \\
\hline Background light attenuation & $\mathrm{a}_{b g}, \mathrm{~m}^{-1}$ & 0.05 & Fasham and Evans (2000) \\
\hline $\mathrm{NH}_{4}$ inhibition parameter & $\Psi,\left(\mu \mathrm{mol} \mathrm{L}^{-1}\right)^{-1}$ & 1.5 & Fasham et al. (1990) \\
\hline *Zooplankton maximum grazing rate & $\begin{array}{l}\mathrm{g}, \mu \mathrm{mol} \text { phyto } \mathrm{C}(\mu \mathrm{mol} \\
\text { zoo } \mathrm{C} \text { day })^{-1}\end{array}$ & 10 & $\begin{array}{l}\text { This study (calculated based on Montagnes and } \\
\text { Lessard, 1999) }\end{array}$ \\
\hline $\begin{array}{l}{ }^{*} \text { Half-saturation constant for zoo- } \\
\text { plankton grazing }\end{array}$ & $\mathrm{k}_{Z}, \mu \mathrm{mol} \mathrm{C} \mathrm{L}{ }^{-1}$ & 15 & $\begin{array}{l}\text { This study (calculated based on Montagnes and } \\
\text { Lessard, 1999) }\end{array}$ \\
\hline Zooplankton growth & day $^{-1}$ & 1.5 & This study \\
\hline $\begin{array}{l}\text { *Phytoplankton to zooplankton con- } \\
\text { version efficiency }\end{array}$ & $\begin{array}{l}\mathrm{c}_{z}, \mu \mathrm{mol} \text { zoo } \mathrm{C}(\mu \mathrm{mol} \\
\text { phyto } \mathrm{C} \text { day })^{-1}\end{array}$ & 0.15 & This study \\
\hline Zooplankton basal losses & $\mathrm{m}_{z}$, day $^{-1}$ & 0.05 & Fasham et al. (1990) \\
\hline Deep water nitrate & $\mathrm{N}_{i n}, \mu \mathrm{mol} \mathrm{L}-1$ & $\begin{array}{l}16.0^{1} \\
24.0^{2}\end{array}$ & World Ocean Atlas (2001) \\
\hline Deep water ammonium & $\mathrm{NH}_{4 i n}, \mu \mathrm{mol} \mathrm{L}-1$ & 1.0 & This study \\
\hline Deep water phosphate & $\mathrm{P}_{i n}, \mu \mathrm{mol} \mathrm{L}^{-1}$ & $\begin{array}{l}1.0^{1} \\
2.5^{2}\end{array}$ & World Ocean Atlas (2001) \\
\hline Deep water silicate & $\mathrm{Si}_{i n}, \mu \mathrm{mol} \mathrm{L}{ }^{-1}$ & $\begin{array}{l}10.0^{1} \\
30.0^{2}\end{array}$ & $\begin{array}{l}\text { World Ocean Atlas (2001) } \\
\text { JGOFS data set }\end{array}$ \\
\hline Deep water iron & $\mathrm{Fe}_{i n}, \mathrm{nmol} \mathrm{L}^{-1}$ & $\begin{array}{l}1.0^{1} \\
0.6^{2}\end{array}$ & $\begin{array}{l}\text { Based on JGOFS PRIME data, Bowie et } \\
\text { al. (2002) and Johnson et al. (1997) }\end{array}$ \\
\hline
\end{tabular}

${ }^{1}$ North Atlantic (NABE), ${ }^{2}$ North Pacific (OSP)

each parameter were determined. These values were used to parameterize the model (Table 2). Depending on a parameter or a group, the median values were determined based on data from 1 to 9 species. We used the carbon-normalized values where appropriate to minimize the effects of cell size. The parameter distributions were compared among groups using either t-tests (pairwise comparisons between groups) or oneway ANOVAs. For many of the parameters, the distributions had means significantly different across groups (Litchman et al., unpublished data). Significant differences in major physiological traits of the functional/taxonomic groups suggest that the average parameter values for each group may be representative of those groups and thus can be used in the taxonomically resolved models of phytoplankton, allowing one to constrain key physiological parameters.

Fe utilization parameters were obtained from Sunda and Huntsman (1995) $\left(Q_{\min }\right)$ and from Maldonado et al. (2001) $\left(V_{\max }\right)$. As there are no published data on Fe utilization by chlorophytes, including prasinophytes, we chose intermediate values (between diatoms and coccolithophores) to represent their $\mathrm{Fe}$-dependent growth and uptake in the model (Table 2). Similarly, intermediate parameter values were used to parameterize chlorophytes in the model by Gregg et al. (2003). Light-dependent growth parameters (maximum growth rate, $\mu_{\max }$ and irradiance half-saturation constant for growth, $k^{I}$ ) were chosen to represent general ranking of the modeled taxonomic groups: diatoms have the lowest half-saturation constant, followed by dinoflagellates, prasinophytes and coccolithophores (Table 2; Brand and Guillard, 1981; Richardson et al., 1983; Langdon, 1988). The maximum growth rates were assumed to be the same as for nutrient-dependent growth.

Zooplankton-related parameters were chosen to represent microzooplankton more than mesozooplankton because grazing at both sites appears to be dominated by the former (Weeks et al., 1993; Frost and Kishi, 1999; Harrison et al., 1999). Maximum ingestion rate, $g$, and the halfsaturation constant for ingestion, $k_{z}$, are taken from the literature for microzooplankton (ciliates; Montagnes and Lessard, 1999). The phytoplankton to zooplankton conversion efficiency was calculated as the maximum zooplankton growth rate $\left(1.5 \mathrm{day}^{-1}\right)$ divided by the maximum grazing rate, $g$. Maximum zooplankton growth rate and the coefficient for zooplankton density-independent mortality are in the range of many models (e.g., Fasham et al., 1990). Some parameters are not well defined in the literature (e.g., grazing preference coefficients for each taxonomic group $c_{i}$ ) and can be quite variable even for the same taxon, with diatoms, however, consistently having the lowest microzooplankton grazing preference coefficient (Gaul and Antia, 2001). For such poorly known parameters we used estimates from other models and allowed for more flexibility (i.e., changed values to improve model predictions), i.e., "free parameters" sensu Fasham et al. (1990) (see Tables 2 and 3 for "fixed" and 
(a)

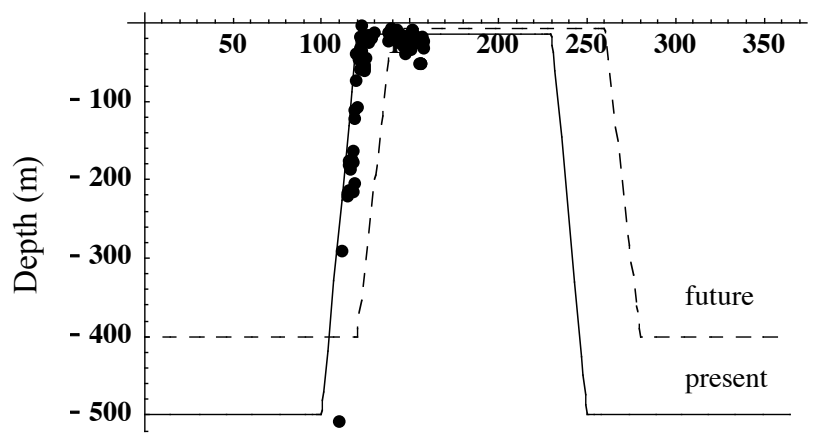

(b)

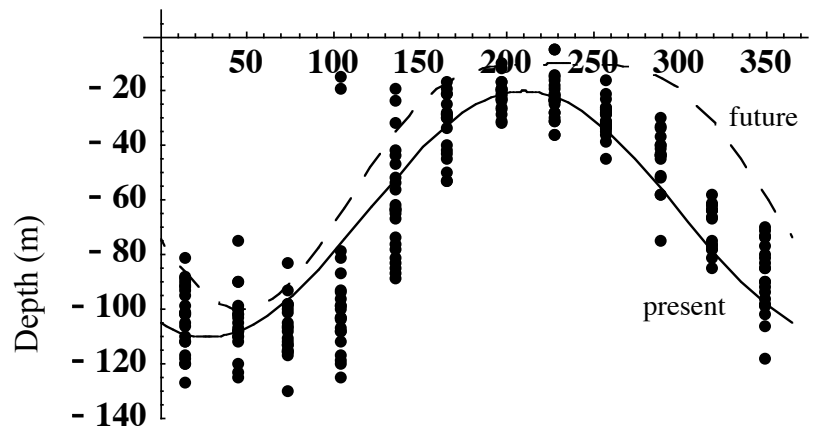

Julian day

Fig. 1. Mixed layer depth (MLD) dynamics at (a) NABE, solid line is the forcing function used in the model and circles are data from the JGOFS compilation (http://dss.ucar.edu/datasets/ds259.0/), also shown is the MLD used in the global change scenarios (dashed line); (b) same as in (a), only for OSP.

"free" parameters). The background light attenuation coefficient (Table 3) is similar to values used in many models (e.g., Evans and Parslow, 1985; Denman and Peña, 1999) and is in the range reported by Kirk (1994) for clear oceanic waters. Phytoplankton attenuation coefficient (same value for all taxonomic groups) was taken from Fasham et al. (1990) and expressed on a per carbon basis assuming the Redfield $\mathrm{C}: \mathrm{N}$ ratio. Predicted carbon concentrations were converted to chlorophyll to compare the phytoplankton biomass with observations. We assumed chlorophyll to carbon ratios (g $\mathrm{Chl}: \mathrm{mol}$ C) of 0.18 for diatoms and 0.48 for coccolithophores and prasinophytes. These coefficients are within the reported values for chlorophyll to carbon ratios and have relative rankings consistent with Geider et al. (1994). We did not model the dynamics of the $\mathrm{C}: \mathrm{Chl}$ ratio as the reliable field data on these ratios in different phytoplankton functional groups are rarely available (Gregg et al., 2003). The cross-thermocline mixing coefficient was taken from Fasham and Evans (2000). The deep-water nitrate, phosphate and silicate concentrations were chosen to be similar to those from the World Ocean Atlas (Levitus, 2001; annual climatological means at $400 \mathrm{~m}$ for NABE and at $110 \mathrm{~m}$ for OSP) and the JGOFS data set (Kleypas and Doney, 2001). Deep water ammonium concentrations were set at $1 \mu \mathrm{M}$ at both sites. Iron concentrations were chosen based on Bowie et al. (2002), Johnson et al. (1997) and iron concentration profiles from the JGOFS PRIME data for NABE (Table 3).

\subsubsection{Seasonal forcing}

The model was forced by seasonal changes in the mixed layer depth and irradiance. The seasonal mixed layer was modeled either by a piecewise linear function (NABE site) or by a power sine function approximating the seasonal mixed layer dynamics (OSP). Both functions closely match the observed mixed layer depth dynamics (Figs. 1a and b). Using the sine function for the North Atlantic site gave qualitatively similar results. Irradiance (daily average PAR, $400-700 \mathrm{~nm}$ ) at the top of the atmosphere for the given latitudes was modeled as in Brock (1981) and the daily PAR reaching the ocean's surface $\left(I_{i n}\right)$ was calculated as in Evans and Parslow (1985). The model equations were solved using Mathematica software (Wolfram Research).

\subsubsection{Taxonomic differences in competitive abilities}

Using the average parameters for each taxonomic/functional group (Table 2), we determined the competitive abilities of all groups for major nutrients (nitrate, ammonium, phosphate and iron). The competitive abilities were characterized using the $R^{*}$ concept, where the best competitor has the lowest $R^{*}$, the resource concentration at which growth equals mortality (Tilman, 1982). For the Droop model formulation, the $R^{*}$ is the following:

$R_{i}^{*}=\frac{k_{i} \mu_{\max , i} Q_{\min , i} m_{i}}{V_{\max , i}\left(\mu_{\max , i}-m_{i}\right)-\mu_{\max , i} Q_{\min , i} m_{i}}$

Symbol definitions and values for each taxonomic group are listed in Table 2. According to this expression, taxonomic groups differ in their competitive abilities for major nutrients: diatoms and coccolithophores are generally good nutrient competitors, having low $R^{*}$ s for all nutrients, and dinoflagellates are poor nutrient competitors (Table 4). As the $R{ }^{*} \mathrm{~s}$ depend on mortalities, we used non-grazing mortalities from the model (Table 2) to estimate groups' competitive abilities. For the given mortalities, coccolithophores and diatoms are good competitors for nitrate and phosphate, and prasinophytes are effective competitors for ammonium but poor competitors for nitrate (Table 4). Based on the chosen Fe utilization parameters, coccolithophores (E. huxleyi) are the best $\mathrm{Fe}$ competitors, followed by dinoflagellates and diatoms and prasinophytes having poorer competitive abilities for $\mathrm{Fe}$. In addition to $R^{*} \mathrm{~s}$ of each group, other ecophysiological characteristics, such as light requirements and 
grazer resistance, contribute to the ecological success of individual species and functional groups. A poor competitor for inorganic nutrients may still persist in the community due to its high grazer resistance.

\subsection{Modern ocean verification}

The model was tested using two data sets from sites that differ considerably in phytoplankton community structure and patterns of seasonal succession. The North Atlantic region, typified by the JGOFS North Atlantic Bloom Experiment site (NABE, $47^{\circ} \mathrm{N} 20^{\circ} \mathrm{W}$ ) exhibits pronounced seasonality with a spring bloom of diatoms often followed by a non-diatom bloom (Joint et al., 1993). Nutrients are depleted seasonally (Longhurst, 1998). The North Pacific region, represented by the Ocean Weather Station Papa (OSP, $50^{\circ} \mathrm{N} 145^{\circ} \mathrm{W}$ ), exhibits much less seasonality in phytoplankton biomass, with no blooms of comparable magnitude and no seasonal depletion of nutrients. OSP resides in a High Nutrient Low Chlorophyll (HNLC) region of the global ocean (Longhurst, 1998; Harrison et al., 1999). Iron (Fe) is likely an important limiting nutrient in this region (Boyd and Harrison, 1999; Tsuda et al., 2003). These two regions of the world ocean are important components in the global carbon cycle and their phytoplankton community structure profoundly affects the magnitude of the carbon flux (Hanson et al., 2000).

The NABE data that we used to validate our model were taken from the JGOFS web site (http://usjgofs.whoi.edu/ jg/dir/jgofs/nabe) and the University Corporation for Atmospheric Research (UCAR) web site (http://dss.ucar.edu/ datasets/ds259.0/). The data for OSP were also obtained from the UCAR web site (Kleypas and Doney, 2001).

The goal of the verification procedure was both qualitative and quantitative agreement with the data, with an emphasis on the presence or absence and relative abundance of certain functional/taxonomic groups, the pattern of seasonal succession, and nutrient dynamics. We describe model results for the two sites. The results reported represent model behavior after it reaches a year-to-year equilibrium, i.e., the pattern is identical from year to year.

\subsection{Modern ocean parameter sensitivity analysis}

We explored how model behavior depends on the model parameters and determined ranges of parameters that produce adequate ecosystem dynamics at each site. A single parameter was altered at a time (Fasham et al., 1990) according to the following scheme: the parameter space was scanned to the left and to the right from the original value (from 0 to 3 times the initial parameter value) using the bisection method (Press et al., 1992). For each new value of the parameter, the model was run to an equilibrium annual cycle that was compared to the model dynamics with the original parameter value. As we are interested in a number of model results including presence/absence and abundance of each tax- onomic group, successional pattern, timing and magnitude of the diatom bloom (at NABE), degree of seasonality in nutrient drawdown, zooplankton abundance, we used multiple criteria to test the model performance with the changed parameter. We summarize these criteria in Table 5. The runs and, consequently, the corresponding parameter values that met all the criteria from Table 5 were considered acceptable. The criteria for model assessment were constrained by the data where possible (Table 5), with better constraints for OSP, as there are multi-year data available for this site. For example, the lower and upper bounds for average yearly concentration of $\mathrm{Si}, \mathrm{N}$ and chlorophyll were determined by the lowest and the highest yearly averages from the time series data for OSP.

\subsection{Global change scenarios}

We considered the following aspects of global change that will likely affect marine phytoplankton communities: global warming-induced changes in mixed layer depth and the duration and timing of the vertical stratification period, shifts in the $\mathrm{N}: \mathrm{P}$ ratios in deep water (increase in $\mathrm{N}$ concentration or a decrease in $\mathrm{P}$ concentration) and changes in iron deposition (both increase and decrease). We applied five hypothetical scenarios to the communities of the two sites we considered here: North Atlantic (NABE) and Subarctic North Pacific (OSP).

\subsubsection{Change in the mixed layer dynamics}

A future increase in atmospheric greenhouse gases will likely change ocean mixed layer dynamics (Manabe et al., 1991; Sarmiento et al., 1998). We constructed scenarios for these changes in mixing dynamics owing to increases in atmospheric $\mathrm{CO}_{2}$ concentration based on simulations of the global coupled atmosphere-ocean-ice model described in Russell et al. (1995) and Miller and Russell (1997). Two 150-year model simulations were used in this study. The first was a control simulation for the present climate in which atmospheric greenhouse gases (GHG) are fixed at 1950 levels. The second was a greenhouse gas simulation in which carbon dioxide concentrations increase at the observed rate between 1950 and 1990 and then increase at a rate of $0.5 \%$ per year from 1990 to 2100 . We used the last ten years of the GHG simulation as the basis for constructing scenarios of changes in mixed layer dynamics at the two sites. It is important to note that because global climate models generally have limited ability to predict changes at single grid boxes, the scenarios here are only representative of possible future outcomes. For the increasing GHG scenario, the model sea surface temperature increased at both sites: 1.5 degrees in winter and 0.85 degrees in summer for the Atlantic site and 1 degree in winter and 0.6 degree in summer for the Pacific site. For the GHG simulation the surface wind stress at both sites is higher than in the control simulation from December to May, the same in June and July, and lower in the fall. 
Table 4. Competitive abilities of major functional groups $\left(R^{*} \mathrm{~s}\right)$ for nitrate, ammonium, phosphate and iron calculated according to Eq. (13) using parameters from Table 2. The lowest $R^{*}$ indicates best competitive abilities for a given nutrient in the absence of grazers.

\begin{tabular}{|c|c|c|c|c|}
\hline $\mathrm{R}^{*}$ & $\begin{array}{l}\text { Ammonium } \\
\left(\mu \mathrm{mol} \mathrm{L}^{-1}\right)\end{array}$ & $\begin{array}{c}\text { Nitrate } \\
\left(\mu \mathrm{mol} \mathrm{L}^{-1}\right)\end{array}$ & $\begin{array}{l}\text { Phosphate } \\
\left(\mu \mathrm{molL}^{-1}\right)\end{array}$ & $\begin{array}{c}\text { Iron } \\
\left(\mathrm{nmol} \mathrm{L}^{-1}\right)\end{array}$ \\
\hline Diatoms & $1.6 \times 10^{-2}$ & $2.8 \times 10^{-2}$ & $3.1 \times 10^{-4}$ & $1.2 \times 10^{-2}$ \\
\hline Dinoflagellates & 2.9 & 6.7 & $9.5 \times 10^{-4}$ & $5.5 \times 10^{-3}$ \\
\hline Coccos & $3.0 \times 10^{-3}$ & $1.7 \times 10^{-2}$ & $1.9 \times 10^{-4}$ & $1.7 \times 10^{-3}$ \\
\hline Greens & $3.0 \times 10^{-3}$ & $1.1 \times 10^{-1}$ & $5.2 \times 10^{-4}$ & $2.3 \times 10^{-2}$ \\
\hline
\end{tabular}

Table 5. Criteria for assessment of the model performance during the parameter sensitivity analysis at each site. $\mathrm{Z}_{\mathrm{max}}$ is the maximum biomass of zooplankton $\left(\mu \mathrm{mol} \mathrm{CL^{-1 }}\right), \mathrm{B}_{\max }$ is the maximum biomass of a given taxonomic group of phytoplankton $\left(\mu\right.$ mol $\left.\mathrm{C} \mathrm{L}^{-1}\right), \mathrm{N}_{\text {, }}$ $\mathrm{N}_{\text {min }}, \mathrm{N}_{\text {avg }}$ and $\mathrm{Si}, \mathrm{Si}_{\min }, \mathrm{Si}_{\text {avg }}$ are the instantaneous, minimum and average (over the annual cycle) nitrate and silicate concentrations ( $\mu \mathrm{M}$ ), respectively. $\overline{\mathrm{Chl}}, \mathrm{Chl}_{\min }$ and $\mathrm{Chl}_{\max }$ are the average, minimum and maximum chlorophyll concentrations over the annual cycle. (a) NABE, (b) OSP.

(a) NABE

\begin{tabular}{ll}
\hline Criterion & Problem reported \\
\hline $\mathrm{Z}_{\max }<0.01$ & No zooplankton \\
$\mathrm{B}_{\max }$, diat $<0.01$ & No diatoms \\
$\mathrm{B}_{\max }$, cocco $<0.01$ & No coccolithophores \\
$\mathrm{B}_{\max }$, green $<0.01$ & No greens \\
$\mathrm{B}_{\max }$, diat $<6.0$ & Diatom maximum too small \\
$\mathrm{B}_{\max }$, diat $>40.0$ & Diatom maximum too big \\
Day of diatom max $<90$ & Diatom maximum too early \\
Day of diatom max $>140$ & Diatom maximum too late \\
Day of cocco max $<$ day of diat max & Cocco max earlier than diatom max \\
Day of cocco max $>250$ & Cocco max too late \\
Day of green max $<$ day of diat max & Green max earlier than diatom max \\
Day of green max $>250$ & Green max too late \\
$\mathrm{N}$ on Julian day $1<3.0$ & $\mathrm{~N}[1]$ too low \\
$\mathrm{Si}$ on Julian day $1<3.0$ & $\mathrm{Si}[1]$ too low \\
$\mathrm{N}_{\min }>1.0$ & $\mathrm{~N}_{\text {min }}$ too high \\
$\mathrm{Si}_{\text {min }}>0.5$ & $\mathrm{Si}$ min too high \\
\hline Chl after day of spring diat max $<0.05$ & $\mathrm{Summer} \overline{\mathrm{Chl}}$ too low too long \\
for $>15$ consecutive days &
\end{tabular}

\begin{tabular}{ll}
\hline (b) OSP & \\
\hline Criterion & Problem reported \\
\hline $\mathrm{Z}_{\max }<0.01$ & No zooplankton \\
$\mathrm{B}_{\max }$, diat $<0.01$ & No diatoms \\
$\mathrm{B}_{\max }$, cocco $<0.01$ & No coccolithophores \\
$\mathrm{B}_{\max }$, green $<0.01$ & No greens \\
$\mathrm{Z}_{\max }>5.0$ & Zooplankton too high \\
$\mathrm{N}_{\text {avg }}<5.5$ & $\mathrm{~N}_{\text {avg too low }}$ \\
$\mathrm{Si}_{\text {avg }}<10.0$ & $\mathrm{Si}_{\text {avg }}$ too low \\
$\mathrm{N}_{\text {avg }}>15.0$ & $\mathrm{~N}_{\text {avg too high }}$ \\
$\mathrm{Si}_{\text {avg }}>25.0$ & $\mathrm{Si}_{\text {avg }}$ too high \\
$\mathrm{Chl}$ min $<0.03$ & $\mathrm{Chl}$ min too low \\
$\mathrm{Chl}$ & \\
$\overline{\mathrm{Chl}}<0.28$ & $\mathrm{Chl}$ max too high \\
$\overline{\mathrm{Chl}}>0.8$ & $\overline{\mathrm{Chl}}$ too low \\
\hline
\end{tabular}


Based on the climate model simulations, scenarios for annual cycles of mixed-layer depth at the two sites are constructed and shown in Figs. 1a and b. Qualitatively, the shoaling of the mixed layer depth at the Atlantic Ocean site occurs about a month later and lasts longer for the GHG scenario due to changes in the wind stress. The mixing depth is slightly shallower in the summer. At OSP the mixed layer depth decreases earlier in the spring and stays shallower longer under the GHG scenario. A decrease in the mixed layer depth at a rate of about $63 \mathrm{~m} /$ century has been already observed at OSP due to warmer temperatures (Freeland et al., 1997; Woody et al., 1999). We quantified these general scenarios as shown in Fig. 1 and applied them to the phytoplankton community model at both sites.

\subsubsection{Change in the deep water N:P ratio}

Small increases in the deep water N:P ratios over several decades have been reported at different parts of the world ocean, including North Atlantic and North Pacific oceans (Pahlow and Riebesell, 2000; Béthoux et al., 2002), although the magnitude and the causes for such shifts are in dispute (Gruber et al., 2000). We increased the deep water N:P ratios at both sites by a) doubling the $\mathrm{N}$ concentration or $\mathrm{b}$ ) halving the $\mathrm{P}$ concentration.

\subsubsection{Change in iron $(\mathrm{Fe})$ deposition}

Increased global mean temperatures will likely alter patterns of atmospheric Fe deposition (Fung et al., 2000). Higher temperatures may lead to higher precipitation and a subsequent decrease in the dust flux, or may increase soil aridity and enhance the aeolian flux. The magnitude and sign of the change are hard to predict because of numerous feedbacks and uncertainties in future land use practices (Fung et al., 2000; Ridgwell, 2002). We explore the effects of both doubled and halved Fe deposition at both sites on phytoplankton community structure. The change in Fe deposition is modeled by changing the deep water Fe concentration, similar to Fennel et al. (2003).

\subsection{Robustness of the future scenario predictions}

The global change scenario predictions may depend idiosyncratically on a given combination of parameter values. It is possible that a different combination of parameters with each of these parameters within its acceptable range may produce a different outcome under global change scenarios and thus decrease the reliability of predictions. This problem is especially acute in models with multiple functional groups, as limited data exist to parameterize such parameter-rich models. To increase the robustness of our model predictions, we used a Monte Carlo approach where the model was run under present conditions with all parameters randomly selected from a predefined range and the model outcome was tested against the chosen criteria (Table 5) to determine how well (a)
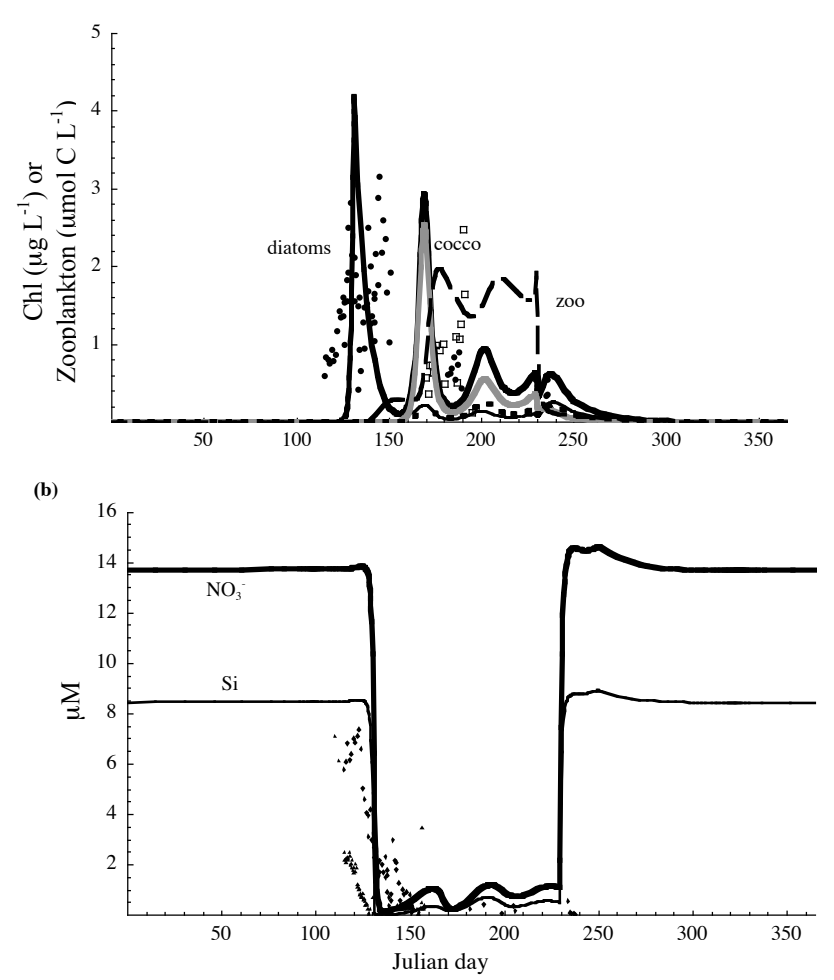

Fig. 2. Annual cycle at NABE of modeled (lines) and observed (symbols) dynamics of (a) phytoplankton (total chlorophyll (modeled - thick solid line and observed - dots), diatoms (thin solid line), coccolithophorids (gray line), prasinophytes (dotted line)) and zooplankton (thick dashed line and open squares); and (b) nitrate (thick solid line and diamonds) and silicate (thin solid line and triangles) after the model reaches quasi-equilibrium.

a given parameter combination predicted modern ecosystem dynamics. This allows us to decrease the effects of uncertainty of model parameterizations. For parameters with a known distribution (based on our database), we used the 25th and 75th percentiles to define the sampling range. For the rest of the parameters the ranges were defined as the parameter value $\pm 1 / 2$ of its value. If the model outcome and, consequently, the given parameter combination were deemed acceptable for the modern ocean sites, the model with this parameter combination was run under all five global change scenarios and the key results such as average biomass of zooplankton and each group of phytoplankton, average nutrient concentrations, timing and magnitude of the diatom bloom (for NABE only) were stored. A total of 100 random parameter combinations that produced acceptable present day model outcomes were run under global change scenarios for each site. For each key variable, the results from each global change scenario were compared with the present day values obtained with the given parameter combination and reported as percent change. To assess the variation in model predictions, we report the 50th, as well as 5th, 25th, 75th and 95th percentiles of the prediction range for 100 acceptable runs. 

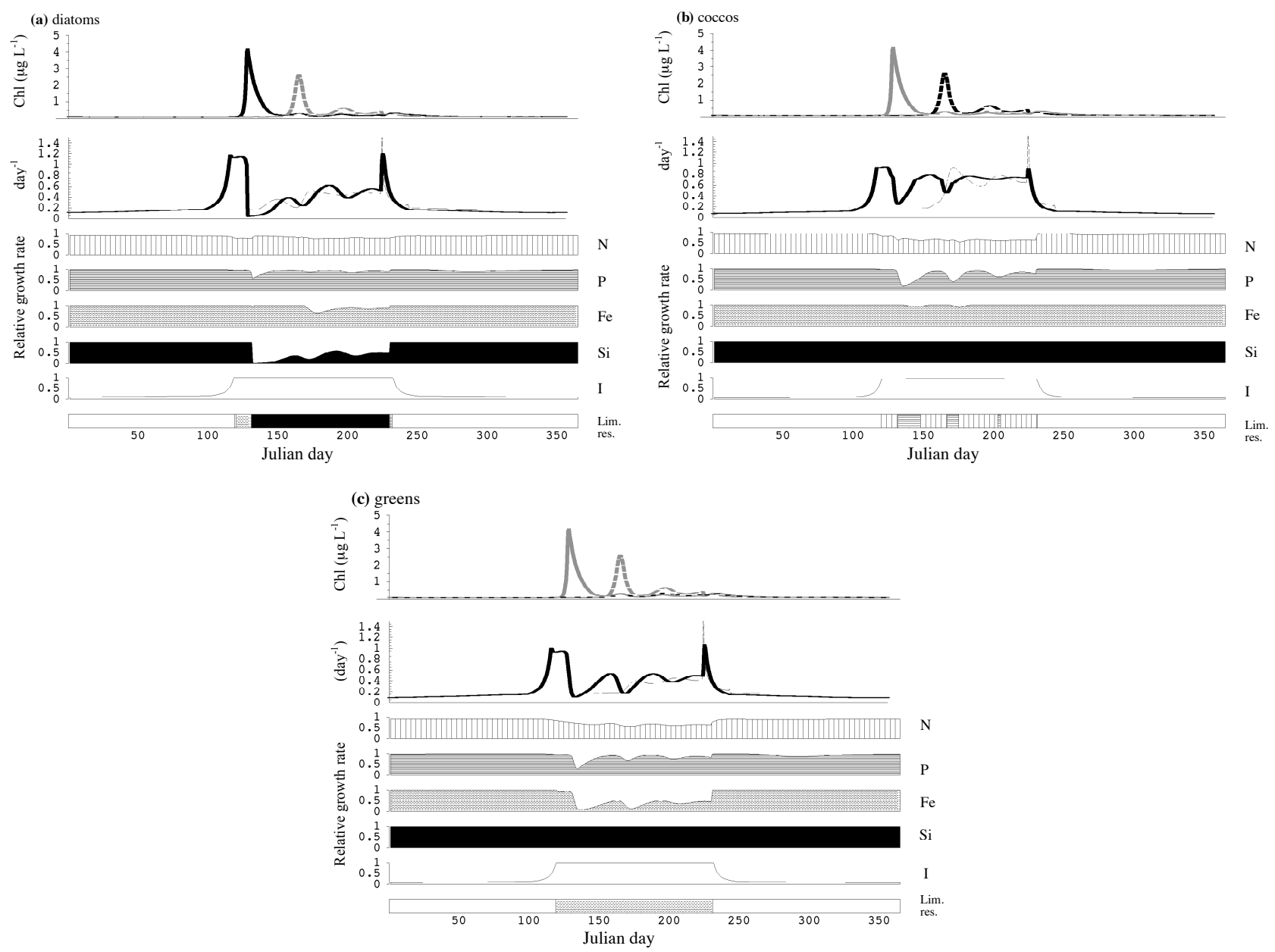

Fig. 3. Seasonal dynamics (over calendar year) of (a) diatom abundance at NABE (first panel, black line; the dynamics of the other two groups are also shown in gray), their growth (solid line) and mortality (dashed line) rates (second panel), the relative contribution of each resource to growth rate (the limiting resource is the resource leading to the lowest relative growth rate) and changes in the limiting resource identity (last panel). (b) same but for coccolithophores and (c) same for prasinophytes.

\section{Results}

\subsection{Modern ocean verification}

\subsubsection{North Atlantic Ocean}

At NABE, a typical seasonal succession pattern consists of low phytoplankton abundance in winter, a spring bloom of diatoms with a subsequent bloom of non-diatom phytoplankton, often coccolithophorids (Emiliania huxleyi) and other flagellates (Lochte et al., 1993; Savidge et al., 1995; Broerse et al., 2000). The model predicts this seasonal succession pattern with the diatom bloom in spring followed by the coccolithophore and flagellate blooms later in the summer (Fig. 2a). All three groups coexisted stably over an annual cycle. This pattern agrees with the JGOFS data and was also predicted by the model of Gregg et al. (2003). The magnitude of the blooms also agrees with the JGOFS data for NABE (Fig. 2a). The nutrient drawdown is highly seasonal, with nitrate, $\mathrm{P}$ and Si becoming depleted in the summer (Fig. 2b). The growth rate of each phytoplankton group in the spring greatly exceeds its mortality rate (Fig. 3, panel 2). The identity of the most limiting resource changes throughout the season and differs among groups (Fig. 3), thus justifying post hoc the need for a multi-nutrient approach. All groups are light-limited in winter, early spring and fall, when mixed layer is deep (Fig. 3). The increases of diatom and later coccolithophore and prasinophyte populations are possible when light-limited growth rate exceeds mortality (Fig. 3). During the stratified period, diatoms are limited mostly by $\mathrm{Si}$ with brief periods of nitrogen and iron limitation, and the spring diatom bloom is terminated due to depletion of Si (Figs. 2 and 3). Growth of coccolithophorids is limited by either $\mathrm{P}$ or $\mathrm{N}$ during the stratified period (Fig. 3b) and prasinophyte 
growth is limited by Fe and controlled by increasing grazer population and later on by the deepened mixed layer and decreased light availability (Fig. 3c). Zooplankton abundance is also highly seasonal, with extremely low density in the winter and higher concentrations associated with phytoplankton blooms (Fig. 2a).

\subsubsection{North Pacific Ocean}

The observed community structure and seasonal patterns are different at OSP from NABE. The biomass of phytoplankton does not exhibit high amplitude seasonal fluctuations. In contrast with the North Atlantic, diatoms do not reach high densities because of severe Fe limitation (Tsuda et al., 2003). The eukaryotic phytoplankton community consists primarily of prymnesiophytes, including coccolithophores, diatoms and prasinophytes. Among coccolithophores, E. huxleyi is the most abundant species (Muggli and Harrison, 1996) and can reach at least $40 \%$ of total phytoplankton biomass (Lam et al., 2001). A characteristic feature of OSP is that prasinophytes contribute significantly to the total cell abundance (Boyd and Harrison, 1999). Coccolithophores can be abundant as well and were previously underestimated (Harrison et al., 2004).

The predicted dynamics of the phytoplankton community in our model agrees well with observations. Diatoms, coccolithophores and prasinophytes coexist stably at this site (Fig. 4a). In contrast to NABE site, over the yearly cycle, total mortality closely follows growth rate for all functional groups (Fig. 5, panel 2). Diatoms do not bloom and their biomass does not reach high values (Figs. 4a and 5a). According to the model, diatoms are limited by light in the beginning and the end of year and by $\mathrm{Fe}$ during the stratified period (Fig. 5a). Coccolithophorid growth is most limited by light and $\mathrm{N}$ with brief periods of Fe limitation (Fig. 5b) and the net growth is controlled by grazing. Prasinophytes are limited by light and Fe and controlled by grazing (Fig. 5c). Total phytoplankton biomass at this site exhibits little seasonality and does not attain values as high as in the North Atlantic (Fig. 4a). There is, however, some seasonality in the abundances of individual groups, with diatoms and prasinophytes achieving higher densities in late fall and winter and coccolithophores in the spring and summer (Figs. 4a and 5). Oscillations in phytoplankton and zooplankton biomass are likely predator-prey cycles and similar oscillations were observed at this site (see OSP data at http://dss.ucar.edu/datasets). Nitrate and Si remain high throughout the year in the model, which agrees with observations (Fig. 4b). Microzooplankton biomass varies ca. fourfold over the season (Fig. 4a), which also corresponds to observations (Boyd et al., 1999).
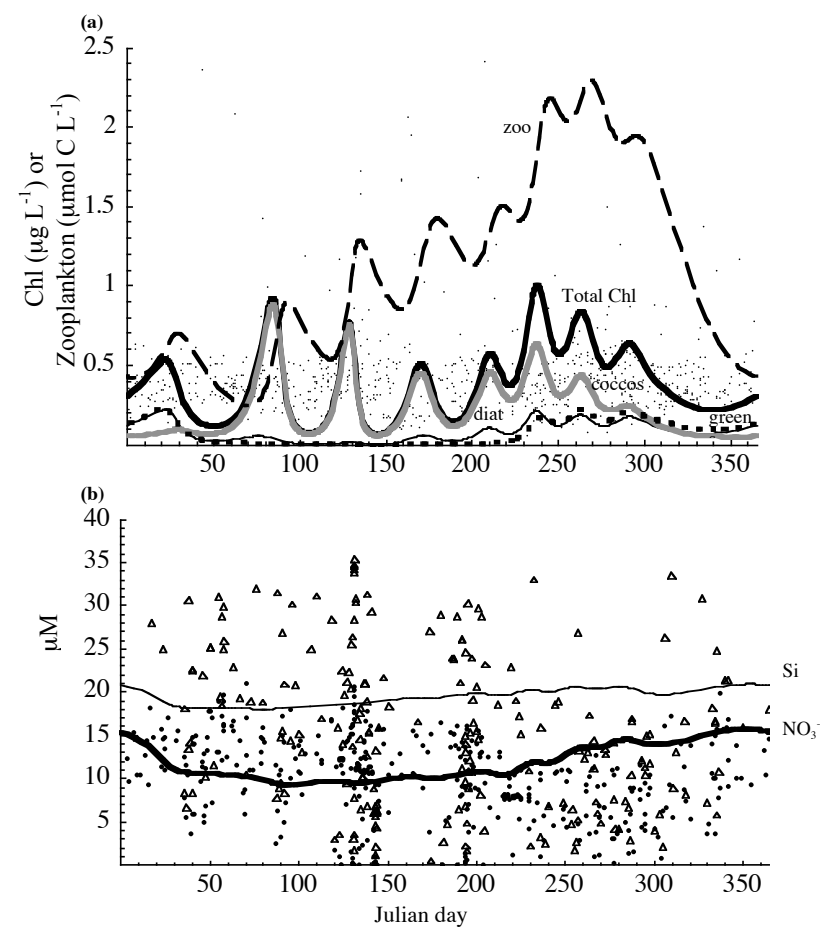

Fig. 4. Ocean Weather Station Papa (OSP), modeled and observed dynamics of (a) phytoplankton (total chlorophyll (predicted - thick solid line and observed - dots), diatoms (thin solid line), coccolithophorids (gray line), prasinophytes (dotted line)) and zooplankton (thick dashed line), (b) nutrients: nitrate (predicted - thick solid line and observed - dots), Si (predicted - thin solid line and observed - triangles).

\subsection{Modern ocean parameter sensitivity analysis}

The results of the sensitivity analysis are given in Table 6 . Different parameters have different sensitivities; some parameters have a large effect on the model outcome and, hence, narrow ranges that produce acceptable model behavior (Table 5) and others do not. Sensitive parameters include phytoplankton maximum growth rates $\left(\mu_{\max }\right)$, minimum $\mathrm{Fe}$ quotas $\left(Q_{\mathrm{min}}^{\mathrm{Fe}}\right)$, Si content of diatoms $\left(Q^{\mathrm{Si}}\right)$, maximum uptake rates for nitrate $\left(V_{\max }^{\mathrm{N}}\right), \mathrm{P}\left(V_{\max }^{\mathrm{P}}\right), \mathrm{Fe}\left(V_{\max }^{\mathrm{Fe}}\right)$, half-saturation constants for uptake of $\mathrm{P}\left(k^{\mathrm{P}}\right), \mathrm{Fe}\left(k^{\mathrm{Fe}}\right)$, light-half saturation constants $\left(k^{\mathrm{I}}\right)$, phytoplankton mortalities $(m)$, groupspecific zooplankton grazing preferences $\left(c_{i}\right)$, background light attenuation $\left(a_{b g}\right)$, zooplankton maximum grazing rate $(g)$, half-saturation constant for zooplankton grazing $\left(k_{z}\right)$, phytoplankton to zooplankton conversion efficiency $\left(c_{z}\right)$ and zooplankton mortality $\left(m_{z}\right)$. Variation in other parameters within the set limits did not affect model results considerably, i.e., the chosen criteria of the model results (Table 5) were met over the whole parameter range.

Another important result that emerged from the sensitivity analysis is that the parameter sensitivity differs between the two sites. Both the identity of the sensitive parameters and 

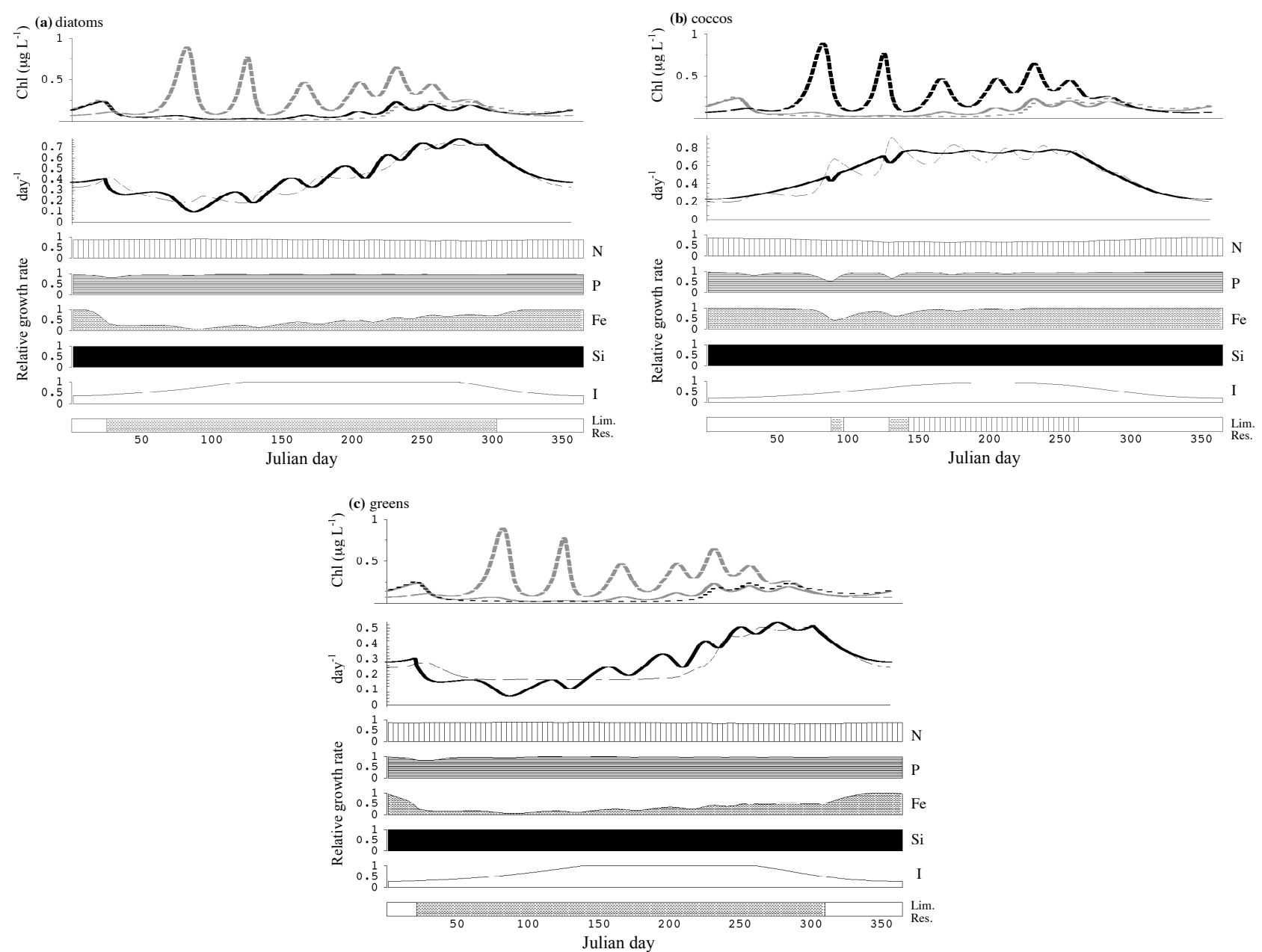

Fig. 5. Same as Fig. 3, only for (a) diatoms, (b) coccolithophores and (c) prasinophytes at OSP.

the acceptable parameter ranges differed between NABE and OSP (Table 5). For example, maximum growth rates are sensitive parameters at both sites, but the ranges are tighter for NABE (Table 6), as at this site phytoplankton have periods of high growth and thus model behavior depends strongly on the maximum growth rate values, while at OSP such periods are shorter due to severe $\mathrm{Fe}$ limitation throughout the year. Also, light is an important factor at NABE as it determines the timing of the spring diatom bloom, and, consequently, model behavior is sensitive to changes in half-saturation constants for light-dependent growth $\left(k^{\mathrm{I}}\right)$ and background light attenuation $\left(a_{b g}\right)$ (Table 6). At OSP, Fe utilization parameters had large influence on the model outcome as evident from the narrow acceptable ranges for those parameters (Table 6). At both sites, grazing parameters (grazing preference for each group, $c_{i}$, zooplankton maximum grazing rate, $g$, half-saturation constant for grazing, $k_{z}$ and phytoplankton to zooplankton conversion efficiency, $c_{z}$ ) had a large effect on model behavior, but the acceptable ranges of those parame- ters were narrower for OSP, thus indicating a relatively larger importance of grazing at this site.

\subsection{Global change scenarios}

Here we report the results of an ensemble of one hundred runs with different parameter combinations that produced adequate modern day dynamics at each site. This increases the robustness of our predictions by diminishing their dependence on a particular parameter combination.

\subsubsection{Change in the mixed layer dynamics}

At NABE the diatom bloom is predicted to occur later in the year, following later stratification, and the magnitude of the bloom will likely decrease (Table 7). The average yearly biomass of diatoms is, however, similar to the present day. In contrast, average biomass of prasinophytes and especially, zooplankton, increases significantly. The average yearly biomass of coccolithophores is more likely to 
Table 6. Results of the parameter sensitivity analysis for NABE and OSP sites. A single parameter was altered at a time. Parameter range (0 to 3 times the original value) was sampled to the left and to the right from the original value using the bisection method (Press et al., 1992). Lower and upper limits define the range for each parameter that produces an acceptable model behavior as defined by the criteria listed in Table 5 with all other parameters at their original value. Parameter limits different from the original range are in bold indicating model sensitivity to this parameter, also listed is the problem in the model behavior for parameter value beyond this limit. If there is no comment by the parameter limit, the results of all runs within the given range met all the criteria listed in Table 5 .

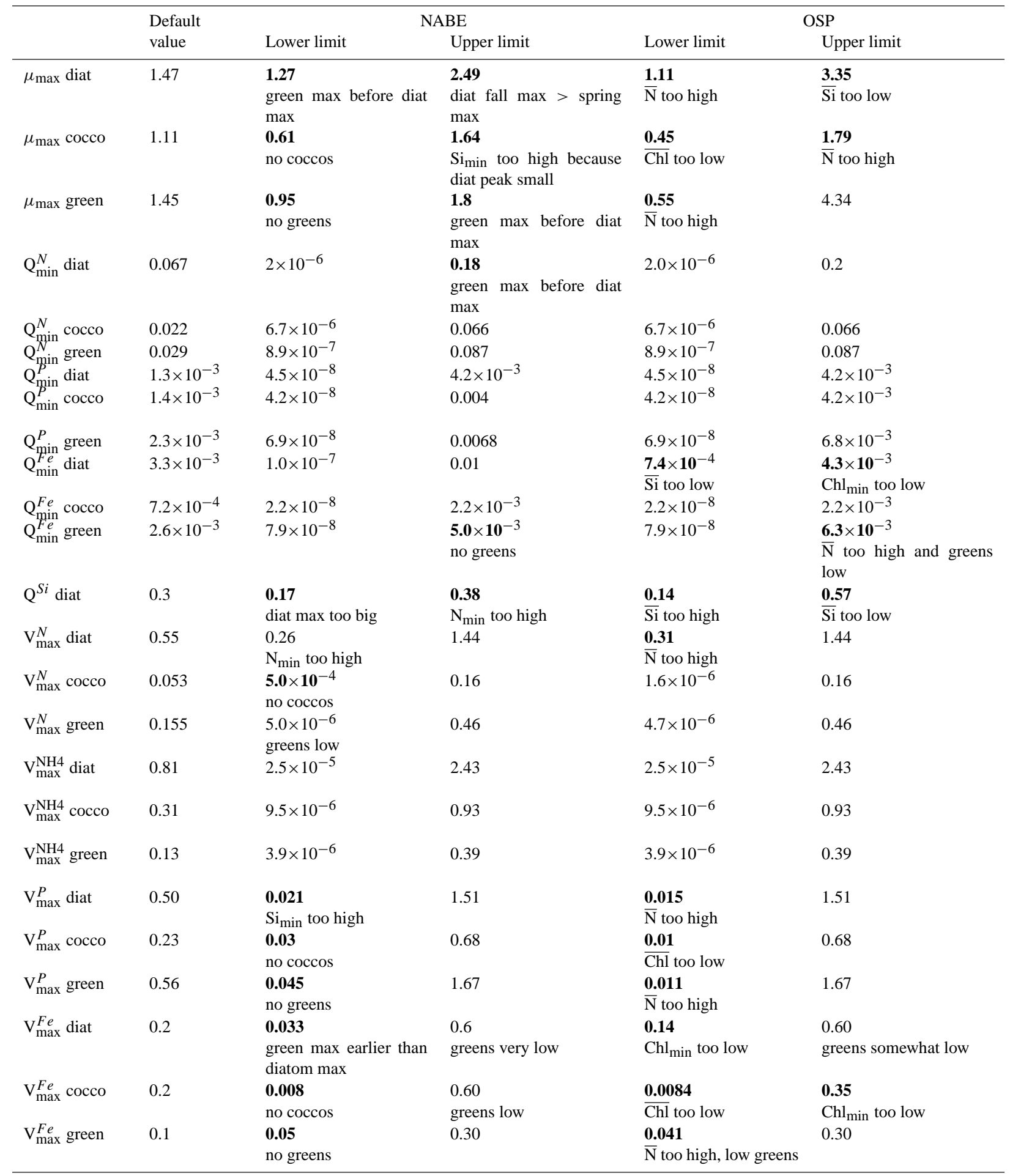


Table 6. Continued.

\begin{tabular}{|c|c|c|c|c|c|}
\hline & Default & & $\mathrm{BE}$ & & SP \\
\hline & value & Lower limit & Upper limit & Lower limit & Upper limit \\
\hline $\mathrm{k}^{N}$ diat & 1.25 & $3.8 \times 10^{-5}$ & 3.75 & $3.8 \times 10^{-5}$ & 3.75 \\
\hline $\mathrm{k}^{N}$ cocco & 0.2 & $6.1 \times 10^{-6}$ & $\begin{array}{l}0.60 \\
\text { greens low }\end{array}$ & $\begin{array}{l}\mathbf{0 . 1 3 5} \\
\mathrm{Chl}_{\min } \text { too low }\end{array}$ & 0.60 \\
\hline $\mathrm{k}^{N}$ green & 3.4 & $1.0 \times 10^{-4}$ & 10.2 & $1.0 \times 10^{-4}$ & 10.2 \\
\hline $\mathrm{k}^{\mathrm{NH} 4}$ diat & 1.1 & $3.3 \times 10^{-5}$ & 3.2 & $3.3 \times 10^{-5}$ & 3.2 \\
\hline $\mathrm{k}^{\mathrm{NH} 4}$ cocco & 0.2 & $6.1 \times 10^{-6}$ & 0.6 & $6.1 \times 10^{-6}$ & 0.6 \\
\hline $\mathrm{k}^{\mathrm{NH} 4}$ green & 0.07 & $2.3 \times 10^{-6}$ & 0.2 & $2.3 \times 10^{-6}$ & 0.2 \\
\hline $\mathrm{k}^{P}$ diat & 0.65 & $\begin{array}{l}\mathbf{0 . 0 5} \\
\text { no coccos }\end{array}$ & 1.95 & $\begin{array}{l}\mathbf{0 . 0 3} \\
\overline{\text { Chl }} \text { too low because } \\
\text { greens and coccos low }\end{array}$ & 1.95 \\
\hline $\mathrm{k}^{P}$ cocco & 0.40 & $1.2 \times 10^{-5}$ & 1.2 & $\begin{array}{l}\mathbf{0 . 0 0 7 6} \\
\text { Chl }_{\min } \text { too low }\end{array}$ & 1.2 \\
\hline $\mathrm{k}^{P}$ green & 0.71 & $\begin{array}{l}\mathbf{0 . 0 2 7} \\
\text { no coccos }\end{array}$ & 2.1 & $\begin{array}{l}\mathbf{0 . 0 1 5} \\
\overline{\mathrm{N}} \text { too high }\end{array}$ & 2.1 \\
\hline $\mathrm{k}^{\mathrm{Fe}}$ diat & 3.3 & $\begin{array}{l}\mathbf{0 . 8 6} \\
\text { no greens }\end{array}$ & 9.9 & $\begin{array}{l}\mathbf{0 . 7 6} \\
\text { no greens }\end{array}$ & $\begin{array}{l}4.9 \\
\mathrm{Chl}_{\min } \text { too low }\end{array}$ \\
\hline $\mathrm{k}^{F e}$ cocco & 2.0 & $\begin{array}{l}\mathbf{0 . 1 4} \\
\text { no greens }\end{array}$ & 6.0 & $\begin{array}{l}\mathbf{1 . 2} \\
\mathrm{Chl}_{\min } \text { too low }\end{array}$ & 6.0 \\
\hline $\mathrm{k}^{F e}$ green & 4.0 & $\begin{array}{l}\mathbf{0 . 0 2 5} \\
\mathrm{Si}_{\text {min }} \text { too high }\end{array}$ & $\begin{array}{l}8.1 \\
\text { no greens }\end{array}$ & $\begin{array}{l}\mathbf{0 . 5 6} \\
\bar{N} \text { too high }\end{array}$ & $\frac{9.9}{N}$ too high, greens low \\
\hline $\mathrm{k}^{I}$ diat & 5.0 & $\begin{array}{l}\mathbf{0 . 9 3} \\
\text { fall diatom } \\
\text { larger than } \\
\text { bloom }\end{array}$ & $\begin{array}{l}\mathbf{8 . 4 3} \\
\text { green max earlier than } \\
\text { diatom max }\end{array}$ & $1.5 \times 10^{-4}$ & $\frac{9.4}{\bar{N} \text { too high }}$ \\
\hline $\mathrm{k}^{I}$ cocco & 7.8 & $\begin{array}{l}2.1 \\
\text { diatom max too small, } \\
\text { coccos bloom early }\end{array}$ & 23.3 & $\begin{array}{l}2.4 \times 10^{-4} \\
\overline{\mathrm{N}} \text { somewhat high }\end{array}$ & 23.3 \\
\hline $\mathrm{k}^{I}$ green & 7.8 & $\begin{array}{l}\text { 4.1 } \\
\text { green max earlier than } \\
\text { diatom max }\end{array}$ & 23.3 & $\begin{array}{l}2.4 \times 10^{-4} \\
\text { Si high }\end{array}$ & 23.3 \\
\hline $\mathrm{k}^{S i}$ diat & 1.0 & $3.1 \times 10^{-6}$ & 3.0 & $3.0 \times 10^{-5}$ & 3.0 \\
\hline a diat & $1.8 \times 10^{-4}$ & $5.5 \times 10^{-9}$ & $5.4 \times 10^{-3}$ & $5.5 \times 10^{-9}$ & $5.4 \times 10^{-3}$ \\
\hline a cocco & $1.8 \times 10^{-4}$ & $5.5 \times 10^{-9}$ & $5.4 \times 10^{-3}$ & $5.5 \times 10^{-9}$ & $5.4 \times 10^{-3}$ \\
\hline a green & $1.8 \times 10^{-4}$ & $5.5 \times 10^{-9}$ & $5.4 \times 10^{-3}$ & $5.5 \times 10^{-9}$ & $5.4 \times 10^{-3}$ \\
\hline $\mathrm{m}$ diat & 0.16 & $\begin{array}{l}\mathbf{0 . 0 8} \\
N_{\text {min }} \text { too high, diat max } \\
\text { too early and small }\end{array}$ & $\begin{array}{l}\text { 0.19 } \\
\text { diat max too small }\end{array}$ & $4.9 \times 10^{-6}$ & $\begin{array}{l}\mathbf{0 . 2} \\
\mathrm{Chl}_{\min } \text { too low }\end{array}$ \\
\hline $\mathrm{m}$ cocco & 0.16 & $\begin{array}{l}\mathbf{0 . 0 8} \\
\text { cocco max earlier than } \\
\text { diat } \max \end{array}$ & $\begin{array}{l}\mathbf{0 . 2 6} \\
\text { no coccos }\end{array}$ & $4.9 \times 10^{-6}$ & $\begin{array}{l}\mathbf{0 . 4 6} \\
\text { Chl too low because coc- } \\
\text { cos low }\end{array}$ \\
\hline$m$ green & 0.16 & $\begin{array}{l}\mathbf{0 . 1 3} \\
\text { green max earlier than } \\
\text { diat } \max \end{array}$ & $\begin{array}{l}0.21 \\
\text { no greens }\end{array}$ & $4.9 \times 10^{-6}$ & $\frac{\mathbf{0 . 2 8}}{\mathrm{N}}$ too high, no greens \\
\hline c diat & 0.8 & $\begin{array}{l}\mathbf{0 . 0 0 9} \\
\text { diat fall bloom larger } \\
\text { than spring bloom, } \\
\mathrm{N}[1] \text { too small }\end{array}$ & 2.4 & $\begin{array}{l}\mathbf{0 . 0 8} \\
\overline{\mathrm{N}} \text { too low }\end{array}$ & $\frac{\mathbf{1 . 4 6}}{\mathrm{N}}$ too high \\
\hline c cocco & 1.0 & $\begin{array}{l}1.5 \times 10^{-4} \\
\text { no greens }\end{array}$ & 3.0 & $\begin{array}{l}\mathbf{0 . 5 2} \\
\overline{\mathrm{N}} \text { too high }\end{array}$ & 3.0 \\
\hline $\mathrm{c}$ green & 1.0 & $\begin{array}{l}\mathbf{1 . 2} \times 10^{-3} \\
\text { no coccos }\end{array}$ & 3.0 & $\begin{array}{l}\mathbf{0 . 0 9} \\
\text { Si too high because } \\
\text { diat low }\end{array}$ & $\begin{array}{l}\mathbf{3 . 0} \\
\text { greens low }\end{array}$ \\
\hline a1 & 0.1 & $\begin{array}{l}\mathbf{0 . 0 3 5} \\
\text { no greens }\end{array}$ & 0.3 & $\begin{array}{l}\mathbf{0 . 0 1 4} \\
\mathrm{Chl}_{\min } \text { too low }\end{array}$ & $\frac{\mathbf{0 . 2 8}}{\bar{N} \text { too high }}$ \\
\hline $\mathrm{a}_{b g}$ & 0.05 & $\begin{array}{l}\mathbf{0 . 0 2 7} \\
\text { fall diat max bigger } \\
\text { than spring diat max }\end{array}$ & $\begin{array}{l}\mathbf{0 . 0 6 7} \\
\text { diat max too late }\end{array}$ & $1.5 \times 10^{-8}$ & $\begin{array}{l}\mathbf{0 . 0 7 7} \\
\mathrm{Chl}_{\min } \text { too low }\end{array}$ \\
\hline$\Psi$ & 1.5 & $4.6 \times 10^{-5}$ & 4.5 & $4.6 \times 10^{-5}$ & 4.5 \\
\hline $\mathrm{g}$ & 10 & $\begin{array}{l}\mathbf{4 . 7 2} \\
\text { no greens }\end{array}$ & $\begin{array}{l}\mathbf{1 6 . 6} \\
\text { summer Chl too low too } \\
\text { long }\end{array}$ & $\begin{array}{l}\mathbf{5 . 2 7} \\
\overline{\mathrm{N}} \text { too low }\end{array}$ & $\begin{array}{l}\mathbf{1 2 . 7} \\
\overline{\mathrm{N}} \text { too high }\end{array}$ \\
\hline
\end{tabular}


Table 6. Continued.

\begin{tabular}{|c|c|c|c|c|c|}
\hline & \multirow{2}{*}{$\begin{array}{l}\text { Default } \\
\text { value }\end{array}$} & \multicolumn{2}{|c|}{ NABE } & \multicolumn{2}{|c|}{ OSP } \\
\hline & & Lower limit & Upper limit & Lower limit & Upper limit \\
\hline \multirow[t]{2}{*}{$\mathrm{k}_{Z}$} & 15 & 8.0 & 34.0 & 11.8 & 29.3 \\
\hline & & $\begin{array}{l}\text { summer Chl too low } \\
\text { too long }\end{array}$ & no greens & $\overline{\mathrm{N}}$ too high & $\overline{\mathrm{N}}$ too low \\
\hline \multirow[t]{2}{*}{$\mathrm{c}_{z}$} & 0.15 & 0.071 & 0.25 & 0.08 & 0.19 \\
\hline & & no greens & $\begin{array}{l}\text { summer Chl too low too } \\
\text { long }\end{array}$ & $\overline{\mathrm{N}}$ too low & $\overline{\mathrm{N}}$ too high \\
\hline \multirow[t]{2}{*}{$\mathrm{m}_{z}$} & 0.05 & 0.019 & 0.11 & 0.04 & 0.09 \\
\hline & & $\begin{array}{l}N_{\min } \text { too high, coccos } \\
\text { and greens low }\end{array}$ & no greens & $\overline{\mathrm{N}}$ too high & $\overline{\mathrm{N}}$ too low \\
\hline \multirow[t]{2}{*}{$\mathrm{N}_{i n}$} & $16.0^{1}$ & 5.0 & 18.5 & 22.3 & 32.5 \\
\hline & $24.0^{2}$ & $\mathrm{~N}[1]$ too low & $N_{\min }$ too high & $\overline{\mathrm{N}}$ too low & $\overline{\mathrm{N}}$ too high \\
\hline $\mathrm{NH}_{4 i n}$ & 1.0 & $3.1 \times 10^{-6}$ & 3.0 & $3.1 \times 10^{-6}$ & 3.0 \\
\hline \multirow{2}{*}{$\mathrm{P}_{i n}$} & $1.0^{1}$ & 0.14 & 3.0 & 0.11 & 7.5 \\
\hline & $2.5^{2}$ & $N_{\min }$ too high & & $\overline{\mathrm{Chl}}$ too low & \\
\hline \multirow[t]{2}{*}{$\mathrm{Si}_{i n}$} & $10.0^{1}$ & 8.0 & 17.0 & 20.5 & 35.5 \\
\hline & $30.0^{2}$ & $N_{\text {min }}$ too high & diat max too big & $\overline{\mathrm{Si}}$ too low & $\overline{\text { Si too high }}$ \\
\hline \multirow[t]{2}{*}{$\mathrm{Fe}_{i n}$} & $1.0^{1}$ & 0.44 & 3.0 & 0.42 & 1.8 \\
\hline & $0.6^{2}$ & no greens & & $\overline{\mathrm{N}}$ too high & $\overline{\mathrm{N}}$ and $\overline{\mathrm{Si}}$ somewhat low \\
\hline
\end{tabular}

increase, although for some parameter combinations it could decrease (Table 7). Nutrients remain at low levels for a larger part of the year due to prolonged stratification. At OSP in the North Pacific, a longer stratification period with a shallower mixed layer depth (Fig. 1b) will lead to an increase in average nitrate and silicate, average biomass of diatoms and prasinophytes, and consequently, of average chlorophyll. Average zooplankton biomass will also increase significantly (Table 7). The average yearly biomass of coccolithophores will likely be similar to the present day.

\subsubsection{Change in the deep water N:P ratio}

In the North Atlantic, the increase of the deep water N:P ratio (by decreasing $\mathrm{P}$ concentration by half, from 1 to $0.5 \mu \mathrm{M}$ P) in deep water leads to lower average coccolithophore biomass, with no major change in the average biomass of green algae and diatoms, but a smaller spring diatom bloom (Table 7). Average chlorophyll concentration and zooplankton biomass will likely decline (Table 7). In the North Pacific, the increase in N:P deep water ratio by halving $\mathrm{P}$ concentration (from 2.5 to $1.25 \mu \mathrm{M}$ ) has a much smaller effect on ecosystem dynamics compared to the North Atlantic site: the magnitude of changes in key variables is much smaller (Table 7). The phytoplankton and zooplankton dynamics retain pronounced seasonality at NABE and low seasonality at OSP. An increase in the N:P deep water ratios by increasing nitrate concentration (2-fold increase) does not have a large effect at the two sites, the community composition and dynamics remain similar to the present day (Table 7).

\subsubsection{Change in iron (Fe) deposition}

Doubling the Fe concentration at NABE (from 1 to $2 \mathrm{nM}$ ) leads to a significant increase in average biomass of prasinophytes, no change in diatom biomass and a decrease in coccolithophore average biomass (Table 7). The average chlorophyll concentration and zooplankton biomass increase. Halving the Fe concentration at NABE (from 1 to $0.5 \mathrm{nM}$ ) strongly decreases prasinophyte abundance, and for some parameter combinations prasinophytes get excluded due to increased iron limitation under this scenario. In contrast, average biomass of coccolithophores increases significantly and diatom biomass as well as the magnitude of spring diatom peak may decline slightly. Total chlorophyll concentration decreases, as well as the microzooplankton biomass.

The doubling the Fe concentration at OSP consistently increases average biomass of diatoms, prasinophytes, average chlorophyll concentration and zooplankton biomass. Coccolithophores decline under this scenario. Nutrients (e.g., $\mathrm{N}, \mathrm{Si}$ ) are utilized more efficiently and their average concentration decreases (Table 7). Halving the Fe concentration leads to a decline in diatoms, prasinophytes, average chlorophyll and zooplankton biomass. For some parameter combinations, prasinophytes are excluded from the community. Coccolithophores increase in abundance. Due to severe $\mathrm{Fe}$ limitation, uptake of macronutrients is lower, leading to their higher average concentrations (Table 7).

\section{Discussion}

Our mechanistic phytoplankton community model with minimal physics captures the principal characteristics of 
Table 7. Present day and global change scenario predictions for key variables. Present day values were obtained with parameter combination given in Tables 2-3. Future changes are expressed as the percent change relative to the present day value of a given variable. The first line for each combination is the 50th percentile, second line are the 25th and 75th percentiles and the third line are the 5th and 95th percentiles of 100 parameter combinations that gave acceptable modern day results for a given site. An increase of the variable is highlighted in bold and a decrease is underlined. $\bar{B}_{\text {diat }}, \bar{B}_{\text {cocco }}$ and $\bar{B}_{\text {green }}$ are the average biomass of diatoms, coccolithophores and green algae (prasinophytes), respectively. $\overline{\mathrm{Chl}}, \bar{B}_{\text {zoop }}$ are the average chlorophyll and zooplankton concentration, respectively. $\mathrm{t}_{\max }$, diat and $\mathrm{B}_{\max }$, diat are the timing (Julian day) of the diatom maximum and its biomass, respectively. $\overline{\mathrm{N}}$ and $\overline{\mathrm{Si}}$ are the average nitrate and silicate concentrations. (a) NABE, (b) OSP.

\begin{tabular}{|c|c|c|c|c|c|c|c|}
\hline NABE & $\begin{array}{l}\bar{B}_{\text {diat }} \\
\mu \mathrm{M} \mathrm{C}\end{array}$ & $\begin{array}{l}\bar{B}_{\text {cocco }} \\
\mu \mathrm{M} \mathrm{C}\end{array}$ & $\begin{array}{l}\bar{B}_{\text {green }} \\
\mu \mathrm{M} \mathrm{C}\end{array}$ & $\begin{array}{l}\overline{\mathrm{Chl}} \\
\mu \mathrm{g} \mathrm{L}^{-1}\end{array}$ & $\begin{array}{l}\bar{B}_{\text {zoop }} \\
\mu \mathrm{M} \mathrm{C}\end{array}$ & $\begin{array}{l}t_{\max } \text {, diat } \\
\text { day }\end{array}$ & $\begin{array}{l}\mathrm{B}_{\max } \text {, diat } \\
\mu \mathrm{M} \mathrm{C}\end{array}$ \\
\hline modern & 0.69 & 0.21 & 0.08 & 0.26 & 0.31 & 131 & 23.2 \\
\hline Change in MLD & $\begin{array}{l}+\mathbf{2 \%} \\
-6 \%,+10 \% \\
(-18 \%,+17 \%)\end{array}$ & $\begin{array}{l}+6 \% \\
-12 \%,+39 \% \\
(-41 \%,+137 \%)\end{array}$ & $\begin{array}{l}+\mathbf{2 6 \%} \\
+\mathbf{+ 4 \% , + 9 1 \%} \\
(-23 \%,+565 \%)\end{array}$ & $\begin{array}{l}+\mathbf{5 \%} \\
-0.5 \%, \quad+12 \% \\
(-16 \%,+33 \%)\end{array}$ & $\begin{array}{l}\mathbf{+ 9 9 \%} \\
\mathbf{+ 7 7 \%},+\mathbf{1 3 2 \%} \\
(+60 \%,+205 \%)\end{array}$ & $\begin{array}{l}+\mathbf{1 0 \%} \\
+\mathbf{9 \%},+\mathbf{1 4 \%} \\
(+7 \%+116 \%)\end{array}$ & $\frac{\frac{-19 \%}{-38 \%,-4 \%}}{(-71 \%+6 \%)}$ \\
\hline $2 \times \mathrm{Fe}$ & $\begin{array}{l}0 \% \\
-2 \%,+2 \% \\
(-23 \%,+5 \%)\end{array}$ & $\frac{\frac{-13 \%}{-35 \%, 0 \%}}{(-81 \%,+12 \%)}$ & $\begin{array}{l}+\mathbf{3 7 \%} \\
\mathbf{+ 6 \%}, \mathbf{+ 1 1 3 \%} \\
(-1 \%,+626 \%)\end{array}$ & $\begin{array}{l}+6 \% \\
+6 \%,+14 \% \\
(-9 \%,+40 \%)\end{array}$ & 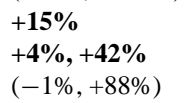 & $\frac{\frac{-1 \%}{-2 \%, 0 \%}}{(-4 \%,+0.2 \%)}$ & $\begin{array}{l}+2 \% \\
-0.1 \%,+9 \% \\
(-46 \%+45 \%)\end{array}$ \\
\hline $1 / 2 \times \mathrm{Fe}$ & $\begin{array}{l}\frac{-5 \%}{-13 \%,+0.5 \%} \\
(-66 \%,+4 \%)\end{array}$ & $\begin{array}{l}+\mathbf{2 2 \%} \\
-1 \%,+114 \% \\
(-14 \%,+732 \%)\end{array}$ & $\frac{\frac{-84 \%}{-100 \%,-50 \%}}{(-100 \%,-10 \%)}$ & $\frac{\frac{-12 \%}{-21 \%,-4 \%}}{(-33 \%,+30 \%)}$ & $\frac{\frac{-18 \%}{-27 \%,-9 \%}}{(-55 \%,+11 \%)}$ & $\begin{array}{l}\mathbf{+ 2 \%} \\
\mathbf{0 . 7 \%},+\mathbf{3 \%} \\
(-0.5 \%+9 \%)\end{array}$ & $\frac{\frac{-8 \%}{-41 \%, 0 \%}}{(-79 \%,+20 \%)}$ \\
\hline $2 \times N$ & $\begin{array}{l}0 \% \\
-0.6 \%,+0.1 \% \\
(-4 \%,+0.7 \%)\end{array}$ & $\begin{array}{l}\frac{-1 \%}{-4 \%,+0.5 \%} \\
(-36 \%,+19 \%)\end{array}$ & $\begin{array}{l}0 \% \\
-3 \%,+5 \% \\
(-6 \%,+41 \%)\end{array}$ & $\begin{array}{l}0 \% \\
-1 \%,+1 \% \\
(-3 \%,+8 \%)\end{array}$ & $\begin{array}{l}+\mathbf{2 \%} \\
+\mathbf{1 1 \%}+\mathbf{7 \%} \\
(0 \%,+30 \%)\end{array}$ & $\begin{array}{l}0 \% \\
\frac{-0.2 \%, 0 \%}{(-0.5 \%,+0.5 \%)}\end{array}$ & $\begin{array}{l}+\mathbf{1} \% \\
\mathbf{0 \%},+2 \% \\
(-5 \%,+4 \%)\end{array}$ \\
\hline $1 / 2 \times \mathrm{P}$ & $\begin{array}{l}\mathbf{+ 0 . 5 \%} \\
-3 \%,+4 \% \\
(-14 \%,+8 \%)\end{array}$ & $\frac{\frac{-30 \%}{-67 \%,-14 \%}}{(-100 \%,+1 \%)}$ & $\begin{array}{l}\frac{-0.5 \%}{-13 \%,+15 \%} \\
(-92 \%,+64 \%)\end{array}$ & $\frac{\frac{-7 \%}{-13 \%},-3 \%}{(-20 \%,+4 \%)}$ & $\frac{\frac{-15 \%}{-33 \%,-8 \%}}{(-54 \%,+1 \%)}$ & $\begin{array}{l}0 \% \\
-0.7 \%+0.4 \% \\
0 \%+1 \%\end{array}$ & $\frac{\frac{-18 \%}{-37 \%,-3 \%}}{(-50 \%,+6 \%)}$ \\
\hline \multicolumn{8}{|l|}{ (b) } \\
\hline OSP & $\begin{array}{l}\bar{B}_{\text {diat }} \\
\mu \mathrm{M} \mathrm{C}\end{array}$ & $\begin{array}{l}\bar{B}_{\text {cocco }} \\
\mu \mathrm{M} \mathrm{C}\end{array}$ & $\begin{array}{l}\bar{B}_{\text {green }} \\
\mu \mathrm{M} \mathrm{C}\end{array}$ & $\begin{array}{l}\overline{\mathrm{Chl}} \\
\mu \mathrm{g} \mathrm{L}^{-1}\end{array}$ & $\begin{array}{l}\bar{B}_{\text {zoop }} \\
\mu \mathrm{M} \mathrm{C}\end{array}$ & $\begin{array}{l}\overline{\mathrm{N}} \\
\mu \mathrm{mol} \mathrm{L}^{-1}\end{array}$ & $\begin{array}{l}\overline{\mathrm{Si}} \\
\mu \mathrm{mol} \mathrm{L}^{-1}\end{array}$ \\
\hline modern & 0.45 & 0.47 & 0.16 & 0.38 & 1.1 & 12.6 & 19.5 \\
\hline Change in MLD & $\begin{array}{l}+\mathbf{2 0} \% \\
+\mathbf{1 4 \%},+\mathbf{2 9 \%} \\
(+6 \%,+40 \%)\end{array}$ & $\begin{array}{l}0 \% \\
-5 \%,+4 \% \\
(-12 \%,+13 \%)\end{array}$ & $\begin{array}{l}\mathbf{+ 3 3 \%} \\
\mathbf{+ 2 1 \%},+\mathbf{7 1 1 \%} \\
(+8 \%,+176 \%)\end{array}$ & $\begin{array}{l}+\mathbf{1 3 \%} \\
+\mathbf{9 \%},+\mathbf{1 6 \%} \\
(+4 \%,+21 \%)\end{array}$ & $\begin{array}{l}\mathbf{+ 3 5 \%} \\
\mathbf{+ 3 2 \% , + 3 9 \%} \\
(+29 \%,+44 \%)\end{array}$ & $\begin{array}{l}\mathbf{+ 2 6 \%} \\
\mathbf{+ 2 0 \%},+\mathbf{3 5 \%} \\
(+14 \%,+57 \%)\end{array}$ & $\begin{array}{l}\mathbf{+ 6 \%} \\
+\mathbf{3 \%},+\mathbf{1 1 1 \%} \\
(-1 \%,+21 \%)\end{array}$ \\
\hline $2 \times \mathrm{Fe}$ & $\begin{array}{l}+\mathbf{2 7 \%} \\
+\mathbf{1 8 \%},+\mathbf{3 4 \%} \\
(+8 \%+59 \%)\end{array}$ & $\frac{\frac{-13 \%}{-18 \%,-7 \%}}{(-28 \%,+1.8 \%)}$ & $\begin{array}{l}\mathbf{+ 4 7 \%} \\
\mathbf{+ 2 8 \% , + 1 1 9 \%} \\
(+14 \%,+224 \%)\end{array}$ & $\begin{array}{l}+\mathbf{1 0 \%} \\
+\mathbf{6 \%},+\mathbf{1 3 \%} \\
(-1 \%,+19 \%)\end{array}$ & $\begin{array}{l}\mathbf{+ 3 2 \%} \\
+\mathbf{2 6 \%},+\mathbf{3 6 \%} \\
(+22 \%,+46 \%)\end{array}$ & $\frac{\frac{-38 \%}{-50 \%,-30 \%}}{(-64 \%,-20 \%)}$ & $\frac{\frac{-27 \%}{-39 \%},-17 \%}{(-67 \%,+10 \%)}$ \\
\hline $1 / 2 \times \mathrm{Fe}$ & $\frac{\frac{-33 \%}{-41 \%,-22 \%}}{(-73 \%,-13 \%)}$ & $\begin{array}{l}+\mathbf{1 0 \%} \\
+\mathbf{+ 4 \%},+\mathbf{1 4 \%} \\
(-4 \%,+21 \%)\end{array}$ & $\frac{\frac{-59 \%}{-100 \%,-32 \%}}{(-100 \%,-19 \%)}$ & $\frac{\frac{-4 \%}{-17 \%,-10 \%}}{(-23 \%,+3 \%)}$ & $\frac{\frac{-32 \%}{-36 \%,-27 \%}}{(-41 \%,-24 \%)}$ & $\begin{array}{l}\mathbf{+ 5 1 \%} \\
\mathbf{+ 4 0 \%},+\mathbf{8 0 \%} \\
(+27 \%,+124 \%)\end{array}$ & $\begin{array}{l}+\mathbf{2 6 \%} \\
+\mathbf{1 8 \%},+\mathbf{4 1} \% \\
(+10 \%,+68 \%)\end{array}$ \\
\hline $2 \times N$ & $\frac{\frac{0 \%}{-0.1 \%,-0.03 \%}}{(-0.2 \%, 0 \%)}$ & $\begin{array}{l}0 \% \\
\mathbf{0 \%}, \mathbf{+ 0 . 0 6 \%} \\
-0 \%,+0.3 \%\end{array}$ & $\frac{\frac{0 \%}{-0.1 \%, 0 \%}}{(-0.2 \%,+0.3 \%)}$ & $\begin{array}{l}\frac{0 \%}{-0.02 \%, 0 \%} \\
(-0.1 \%, \\
+0.1 \%)\end{array}$ & $\begin{array}{l}0 \% \\
\mathbf{0 \%},+\mathbf{+ 0 . 1} \% \\
(0 \%,+0.3 \%)\end{array}$ & $\begin{array}{l}\mathbf{+ 2 6 3 \%} \\
\mathbf{+ 2 2 5 \%},+\mathbf{3 1 3} \% \\
(+206 \%,+423 \%)\end{array}$ & $\begin{array}{l}0 \% \\
\mathbf{0 \%},+\mathbf{+ 0 . 1 \%} \\
(0 \%,+0.1 \%)\end{array}$ \\
\hline $1 / 2 \times \mathrm{P}$ & $\begin{array}{l}0 \% \\
\mathbf{0 \%},+\mathbf{0 . 7 \%} \\
(-1 \%,+8 \%)\end{array}$ & $\begin{array}{l}0 \% \\
\frac{-0.6 \%, 0 \%}{(-6 \%,+0.5 \%)}\end{array}$ & $\begin{array}{l}0 \% \\
-0.5 \%,+0.3 \% \\
(-4 \%,+5.8 \%)\end{array}$ & $\begin{array}{l}0 \% \\
\frac{-0.3 \%, 0 \%}{(-1 \%,+0.7 \%)}\end{array}$ & $\begin{array}{l}0 \% \\
-3 \%,+0.1 \% \\
(-10 \%, 0 \%)\end{array}$ & $\begin{array}{l}0 \% \\
-0.1 \%,+0.4 \% \\
(-3 \%,+2 \%)\end{array}$ & $\begin{array}{l}0 \% \\
\frac{-0.3 \%, 0 \%}{(-3 \%,+0.4 \%)}\end{array}$ \\
\hline
\end{tabular}

phytoplankton dynamics over the annual cycle. The model is capable of reproducing the distinctly different patterns of abundance and succession at two characteristic sites of the ocean. Although we aimed at developing a simple model, we included multiple nutrients that can limit phytoplankton growth, e.g., $\mathrm{P}$, which is often omitted from the ocean phytoplankton models. There are compelling reasons to include $\mathrm{P}$ into the models of marine phytoplankton. Our data compilation shows that major taxonomic groups differ in their competitive abilities not only for $\mathrm{N}$ but $\mathrm{P}$ as well. Therefore, including growth dependence on $\mathrm{P}$ allows for better separation of different functional groups. Moreover, some regions of the ocean are P-limited at present and the extent of such areas may increase in the future (Ammermann et al., 2003). The model also predicts limitation by multiple resources over the course of the year. Using Droop formulations for major nutrients also allows for non-Redfield phytoplankton stoichiometry and carbon and nutrient drawdown ratios (Klausmeier et al., 2004), observed at these sites (Bury et al., 2001). 
As we aimed at modeling phytoplankton community structure, we did not include some key ecosystem variables such as bacteria or dissolved organic matter. Instead, we concentrated on adequately describing major ecological controls of the main functional groups of eukaryotic phytoplankton, such as nutrients, light and grazing. The community composition and succession are sensitive not only to the levels and ratios of resources but to grazing parameters as well. It is likely that models with greater taxonomic resolution of phytoplankton are more sensitive to grazing parameter values than models considering only total chlorophyll dynamics. A high sensitivity to grazing parameters has been observed in other ecosystem models (see references in Peña, 2003) and underscores the importance of quantifying grazer impact on community structure. A systematic parameter sensitivity analysis revealed other sensitive parameters and the ranges that produce acceptable model behavior. Where possible, we compared the acceptable ranges of parameters obtained in the sensitivity analysis with parameterizations from other models of multiple phytoplankton functional groups (e.g., Moore et al., 2002; Gregg et al., 2003). In many cases those parameterizations fall within our estimated ranges (e.g., maximum growth rates).

Predicting phytoplankton community patterns under future scenarios is uncertain due to difficulties in parameterization and may depend on model structure and parameter combinations. We explored this uncertainty using Monte Carlo techniques where future scenarios are run with multiple parameter combinations that produced acceptable modern day dynamics. To our knowledge, this is the first such attempt to reduce the uncertainty of predictions in a model with multiple phytoplankton functional groups. Our future predictions are based on randomly chosen parameter sets that get the modern dynamics right. Most of the model predictions are qualitatively robust, with key variables showing the same pattern of change independent of the parameter combination. For example, a decrease in Fe concentration robustly increases the abundance of coccolithophores and decreases the prasinophyte abundance at both sites (Table 7). Similarly, average zooplankton biomass will likely increase significantly under the predicted changes in MLD dynamics at both sites. The magnitude of change in key variables is, however, more dependent on the parameter combinations.

The competitive rankings of major taxonomic groups based on experimental data and our model predictions are consistent with the observed patterns of the community structure in the ocean. Diatoms grow at lower light, have high maximum growth rates and, as our results suggest, are good $\mathrm{N}$ competitors. These traits enable them to increase ahead of other groups as irradiance increases due to spring increase in solar declination and shoaling of the mixed layer (Sverdrup, 1953). A later onset of stratification delays the occurrence of spring diatom bloom. With a shallower mixed layer depth, light availability increases, thus, diminishing the competitive advantage of diatoms. Consequently, as pre- dicted by the model, the magnitude of the spring diatom bloom decreases with longer stratification period under the global change scenario. At the same time, coccolithophores and prasinophytes, having higher half-saturation constants for light-dependent growth, are likely to increase under this scenario at NABE (Table 7). Stimulation of coccolithophores by prolonged stratification has been observed in the Bering Sea, where an unusually long stratification period in 1997 and 1998 had lead to massive coccolithophore blooms (Napp and Hunt, 2001; Iida et al., 2002). Recent global satellite data analysis also showed strong association of coccolithophore blooms with highly stratified conditions (Iglesias-Rodrígues et al., 2002).

Dinoflagellates have parameter combinations that result in a less efficient acquisition of inorganic nitrogen and phosphate, compared to other groups, as per the compilation of literature data. These characteristics do not allow for their persistence under limitation by those nutrients. Future improvements of the model should include the mixotrophic mode of nutrition by dinoflagellates. Including of the mixotrophy for dinoflagellates (prey ingestion and higher growth efficiency at low light) in a recent model by Fulton et al. (2004) allowed for persistence of dinoflagellates, while with the phototrophic mode of nutrition only dinoflagellates declined to negligible densities (Fulton et al., 2004).

As our analysis suggests, prasinophytes are relatively poor nitrate competitors (Table 4) and, consequently, they can be abundant where nitrate is not depleted (HNLC regions). For example, at OSP (HNLC region) high prasinophyte abundance is observed (Varela and Harrison, 1999) and predicted by our model. According to the available data on Fe utilization, coccolithophores are good Fe competitors and, consequently, increase under decreased $\mathrm{Fe}$ deposition, while diatoms and prasinophytes decline. Our predicted long-term effects of the $\mathrm{Fe}$ concentration increase such as the increase of diatoms in the HNLC areas and a more efficient nutrient drawdown agree well with the short-term experimental Fe fertilization results (Boyd et al., 2000; Tsuda et al., 2003) and with the predictions of other models (Moore et al., 2004). Other predictions are less intuitive, such as the decrease of coccolithophores at both sites under increased $\mathrm{Fe}$ deposition. Increased $\mathrm{Fe}$ availability decreases the importance of $\mathrm{Fe}$ competition and allows poorer Fe competitors (diatoms and prasinophytes) to dominate. Our results on community shifts under various Fe deposition scenarios are greatly dependent on the group-specific Fe utilization parameters. More experimental data on Fe-dependent growth and uptake by major phytoplankton groups, e.g., prasinophytes, are critical for generating credible predictions.

Changes in nutrient ratios in deep waters have been observed in various parts of the ocean. For example, in the Mediterranean Sea the Si:P ratio has declined due to an anthropogenic increase in phosphate input over the last few decades (Béthoux et al., 2002). Physical mixing brings nutrients at altered ratios to the upper ocean. Consequently, 
changes in ambient nutrient ratios may shift community composition due to differential requirements and competitive abilities of the phytoplankton functional groups for major nutrients.

Based on our literature survey, it appears that major functional groups are significantly different in their nutrient utilization patterns and competitive abilities. We have included these differences in the model. However, a number of parameters that are likely to be group-specific (light-attenuation coefficients, ammonium inhibition constants, maximum grazing rates and phytoplankton to zooplankton conversion efficiencies) were assumed to be the same for all groups. Possible refinements of the model can include a group-specific choice of the above-mentioned parameters or including other physiological processes such as photoinhibition. This will allow for an even greater separation of different functional groups. In addition, nitrogen fixers (cyanobacteria) must be included to apply the model to other sites (e.g., tropics and subtropics) in the global ocean. They can also be explicitly modeled in the future versions of this model to more fully explore the effects of warming at NABE and OSP, as increased temperatures may stimulate nitrogen fixation. We do not include an explicit temperature dependence of physiological processes as the immediate goal was to explore the indirect effects of global warming on the phytoplankton community structure but such dependence may also be included in the future versions of the model. Other factors not included in the model may also be important: increased $\mathrm{CO}_{2}$ will likely lower the $\mathrm{pH}$ of the ocean and this may have a drastic effect on calcifying organisms, including coccolithophores (Orr et al., 2005). The rates of calcification and growth of the coccolithophore Emiliania huxleyi decrease under high $p \mathrm{CO}_{2}$ and may shift community dominance to non-calcifying phytoplankton (Engel et al., 2005).

In our model each functional group is represented by one composite "species" with the key parameter values averaged over a range of species. Thus, the model is capable of describing only the "average" behavior of each group. Future refinements could explicitly model within-group variability (e.g., size-related differences) by including more than one compartment for each taxonomic group.

Our study indicates that changes in mixed layer dynamics may change both the timing and magnitude of the phytoplankton blooms as well as community composition. Significant changes in community composition due to climatic alterations are being observed in the world ocean and are referred to as the "domain shift hypothesis" (Karl et al., 2001). A disappearance of individual species or functional groups as predicted in some global change scenarios may have a dramatic effects on community and ecosystem dynamics (Berlow, 1999). The later timing and smaller magnitude of the diatom bloom in the North Atlantic under the increased greenhouse gas scenario may have profound consequences for higher trophic levels, e.g., the survival of larval stages of the commercial fish populations. A recent study showed that the timing of the phytoplankton bloom accounted for $89 \%$ of variance in the survival of larval haddock in the North Atlantic, where a 5-week delay in spring bloom decreased the fish survival index more than 5-fold (Platt et al., 2003). Historic variation in the mixed layer dynamics and consequent changes in primary productivity have been shown to affect commercial fisheries in the Pacific as well (Chavez et al., 2002).

The scenarios for changes in mixed layer dynamics are based on simulations of a global climate model and should be considered only as representative of possible future outcomes. Global models are still not very reliable for making predictions for changes at specific sites. Predicting changes in mixed layer depth are particularly difficult because they require accurate representation of changes in ocean temperature and salinity and atmospheric wind stress. Another factor complicating predictions of the future ecosystem dynamics is the potential phenotypic or genotypic changes in phytoplankton and zooplankton's eco-physiological traits induced by climate change. Such changes are not considered by our model, as they are poorly known. They, however, may set ecosystem dynamics on trajectories very different from the ones predicted by our model.

Increased concentration of greenhouse gases may alter stratification patterns and reduce Fe deposition. Our results indicate that these key consequences of global change may shift competitive interactions among phytoplankton and decrease diatom distribution and abundance in different parts of the world ocean. Decreased diatom abundance may in turn decrease efficiency of carbon export production (carbon sequestration) and increase $\mathrm{CO}_{2}$ in the atmosphere, thus creating a positive feedback between phytoplankton community structure and climate change. The predicted shift toward dominance by coccolithophores under some global change scenarios would enhance biocalcification and thus significantly change $p \mathrm{CO}_{2}$ (Doney et al., 2000) and global albedo (Tyrrell et al., 1999). The predicted increase in prasinophyte abundance may also significantly alter carbon sequestration patterns and trophic interactions by stimulating microzooplankton growth. Human-induced changes in physico-chemical ocean characteristics almost certainly will alter the structure of phytoplankton communities and thus have a profound effect on ecosystem structure and global biogeochemical cycles. Using composite characteristics of major taxonomic groups based on the extensive experimental data compilation may allow for meaningful parameterizations of phytoplankton community models that can then be used for qualitative predictions amenable to mechanistic interpretation. 


\section{Appendix A References used to obtain data for Table 2}

Bhovichitra, M. and Swift, E.: Light and dark uptake of nitrate and ammonium by large oceanic dinoflagellates: Pyrocystis noctiluca, Pyrocystis fusiformis, and Dissodinium lunula, Limnol. Oceanogr., 22, 73-83, 1977.

Bienfang, P. K.: Steady-state analysis of nitrate-ammonium assimilation by phytoplankton, Limnol. Oceanogr., 20, 402-411, 1975.

Caperon, J. and Meyer, J.: Nitrogen-limited growth of marine phytoplankton. 2. Uptake kinetics and their role in nutrient limited growth of phytoplankton, Deep-Sea Res., 19, 612-632, 1972.

Carpenter, E. J. and Guillard, R. R. L.: Intraspecific differences in nitrate half-saturation constants for three species of marine phytoplankton, Ecology, 52, 183-185, 1971.

Cembella, A. D., Antia, N. J., and Harrison, P. J.: The utilization of inorganic and organic phosphorus compounds as nutrients by eukaryotic microalgae: a multidisciplinary perspective: part 1, CRC Crit. Rev. Microbiol., 10, 317-391, 1984.

Cochlan, W. P. and Harrison, P. J.: Kinetics of nitrogen (nitrate, ammonium and urea) uptake by picoflagellate Micromonas pusilla (Prasinophyceae), J. Exp. Mar. Biol. Ecol., 153, 129-141, 1991.

Conway, H. L. and Harrison, P. J.: Marine diatoms grown in chemostats under silicate or ammonium limitation. IV Transient response of Chaetoceros debilis, Skeletonema costatum and Thalassiosira gravida to a single addition of the limiting nutrient, Mar. Biol., 43, 33-43, 1977.

Davidson, K. and Gurney, W. S. C.: An investigation of non-steadystate algal growth. II. Mathematical modelling of co-nutrientlimited growth, J. Plankton Res., 21, 839-858, 1999.

Deane, E. M. and O'Brien, R. W.: Uptake of phosphate by symbiotic and free-living dinoflagellates, Arch. Microbiol., 128, 307310, 1981.

Eppley, R. W. and Coatsworth, J. L.: Nitrate and nitrite uptake by Ditylum brightwellii: kinetics and mechanisms, J. Phycol., 4, 151156, 1968.

Eppley, R. W. and Renger, E. M.: Nitrogen assimilation of an oceanic diatom in nitrogen-limited continuous culture, J. Phycol., 18, 534-551, 1974.

Eppley, R. W., Rogers, J. N., and McCarthy, J. J.: Half-Saturation Constants for Uptake of Nitrate and Ammonium by Marine Phytoplankton, Limnol. Oceanogr., 14, 912-920, 1969.

Goldman, J. C. and Glibert, P. M.: Comparative rapid ammonium uptake by four species of marine phytoplankton, Limnol. Oceanogr., 27, 814-827, 1982.

Graziano, L. M., Roche, J. L., and Geider, R. J.: Physiological responses to phosphorus limitation in batch and steady-state cultures of Dunaliella tertiolecta (Chlorophyta): a unique stress protein as an indicator of phosphate deficiency, J. Phycol., 32, 825-838, 1996.

Kanda, J. and Hattori, A.: Ammonium uptake and synthesis of cellular nitrogenous macromolecules in phytoplankton, Limnol. Oceanogr., 33, 1568-1579, 1988.

Koike, I., Redalje, D. G., Ammerman, J. W., and Holm-Hansen, O.: High-affinity uptake of an ammonium analogue by two marine microflagellates from the oligotrophic Pacific, Mar. Biol., 74, 161168, 1983.
Parslow, J. S., Harrison, P. J., and Thompson, P. A.: Development of rapid ammonium uptake during starvation of batch and chemostat cultures of the marine diatom Thalassiosira pseudonana, Mar. Biol., 83, 43-50, 1984a.

Parslow, J. S., Harrison, P. J., and Thompson, P. A.: Saturated uptake kinetics: transient response of the marine diatom Thalassiosira pseudonana to ammonium, nitrate, silicate or phosphate starvation, Mar. Biol., 83, 51-59, 1984b.

Perry, M. J.: Phosphate utilization by an oceanic diatom in phosphorus-limited chemostat culture and in the oligotrophic waters of the central North Pacific, Limnol. Oceanogr., 21, 88-107, 1976.

Reay, D. S., Nedwell, D. B., Priddle, J., and Ellis-Evans, J. C.: Temperature dependence of inorganic nitrogen uptake: reduced affinity for nitrate at suboptimal temperatures in both algae and bacteria, Appl. Environ. Microbiol., 65, 2577-2584, 1999.

Rhodes, L. L., Peake, B. M., Mackenzie, A. L., and Marwick, S.: Coccolithophores Gephyrocapsa oceanica and Emiliania huxleyi $($ Prymnesiophyceae $=$ Haptophyceae $)$ in New Zealand's coastal waters: Characteristics of blooms and growth in laboratory culture, New Zealand J. Mar. Freshwater Res., 29, 345-357, 1995.

Riegman, R., Stolte, W., Noordeloos, A. A. M., and Slezak, D.: Nutrient uptake and alkaline phosphatase (EC 3:1:3:1) activity of Emiliania huxleyi (Prymnesiophyceae) during growth under $\mathrm{N}$ and P limitation in continuous cultures, J. Phycol., 36, 87-96, 2000.

Rivkin, R. B. and Swift, E.: Phosphate uptake by the oceanic dinoflagellate Pyrocystis noctiluca, J. Phycol., 18, 113-120, 1982.

Shuter, B. J.: Size dependence of phosphorus and nitrogen subsistence quotas in unicellular microorganisms, Limnol. Oceanogr., 23, 1248-1255, 1978.

Smayda, T. J.: Harmful algal blooms: Their ecophysiology and general relevance to phytoplankton blooms in the sea, Limnol. Oceanogr., 42, 1137-1153, 1997.

Tarutani, K. and Yamamoto, T.: Phosphate uptake and growth kinetics of Skeletonema costatum isolated from Hiroshima Bay, L. Fac. Appl. Biol. Sci., 33, 59-64, 1994.

Terry, K. L., Hirata, J., and Laws, E. A.: Light-, nitrogen-, and phosphorus-limited growth of Phaeodactylum tricornutum Bohlin strain TFX-1: chemical composition, carbon partitioning and diel periodicity of physiological processes, J. Exp. Mar. Biol. Ecol., 86, 85-100, 1985.

Vargo, G. A. and Howard-Shamblott, D.: Phosphorus dynamics in Ptychodiscus brevis: cell phosphorus, uptake and growth requirements, in: Toxic marine phytoplankton, edited by: Granéli, E., Sundström, B., Edler, L., and Anderson, D. M., Elsvier, New York, pp. 324-329, 1990.

Wynne, D. and Rhee, G.-Y.: Effects of light intensity and quality on the relative $\mathrm{N}$ and $\mathrm{P}$ requirement (the optimum $\mathrm{N}: \mathrm{P}$ ratio) of marine planktonic algae, J. Plankton Res., 8, 91-103, 1986.

Yamaguchi, M., Itakura, S., and Uchida, T.: Nutrition and growth kinetics in nitrogen- or phosphorus-limited cultures of the "novel red tide" dinoflagellate Heterocapsa circularisquama (Dinophyceae), Phycologia, 40, 313-318, 2001.

Yamamoto, T., Oh, S. J., and Kataoka, Y.: Growth and uptake kinetics for nitrate, ammonium and phosphate by the toxic dinoflagellate Gymnodinium catenatum isolated from Hiroshima Bay, Japan, Fish. 
Sci., 70, 108-115, 2004.

Yamamoto, T. and Tarutani, K.: Growth and phosphate uptake kinetics of the toxic dinoflagellate Alexandrium tamarense from Hiroshima Bay in the Seto Inland Sea, Japan, Phycol. Res., 47, 27-32, 1999.

Zehr, J. P., Falkowski, P. G., Fowler, J., and Capone, D. G.: Coupling between ammonium uptake and incorporation in a marine diatom: experiments with the short-lived radioisotope ${ }^{13} \mathrm{~N}$, Limnol. Oceanogr., 33, 518-527, 1988.

Zondervan, I., Rost, B., and Riebesell, U.: Effect of $\mathrm{CO}_{2}$ concentration on the PIC/POC ratio in the coccolithophore Emiliania huxleyi grown under light-limiting conditions and different daylengths, J. Exp. Mar. Biol. Ecol., 272, 55-70, 2002.

Acknowledgements. This work was in part supported by a NASA SMP grant to P. G. Falkowski, NSF grants OCE-0084032 (to P. G. Falkowski and O. M. Schofield), DEB-0083566 and Andrew W. Mellon Foundation grant (to S. A. Levin), DEB-0610531 (to E. Litchman and C. A. Klausmeier) and DEB-0610532 (to C. A. Klausmeier and E. Litchman). We thank G. Russell for providing output from the global climate model and K. Fennel, T. Richardson and the anonymous referees for helpful comments.

Edited by: C. Heinze

\section{References}

Ammerman, J. W., Hood, R. R., Case, D. A., and Cotner, J. B.: Phosphorus deficiency in the Atlantic: an emerging paradigm in oceanography, EOS, 84, 165, 2003.

Balch, W. M., Holligan, P. M., and Kilpatrick, K. A.: Calcification, photosynthesis and growth of the bloom-forming coccolithophore, Emiliania huxleyi, Continental Shelf Res., 12, 13531374, 1992.

Barlow, R. G., Mantoura, R. F. C., Peinert, R. D., Miller, A. E. J., and Fileman, T. W.: Distribution, sedimentation and fate of pigment biomarkers following thermal stratification in the Western Alboran Sea, Marine Ecology Progress Series, 125, 279-291, 1995.

Bissett, W. P., Walsh, J. J., Dieterle, D. A., and Carder, K. L.: Carbon cycling in the upper waters of the Sargasso Sea. I. Numerical simulation of differential carbon and nitrogen fluxes, Deep-Sea Res. I, 46, 205-269, 1999.

Brand, L. E. and Guillard, R. R. L.: The effects of continuous light and light intensity on the reproduction rates of twenty-two species of marine phytoplankton, J. Exp. Mar. Biol. Ecol., 50, 119-132, 1981.

Berlow, E. L.: Strong effects of weak interactions in ecological communities, Nature, 398, 330-334, 1999.

Béthoux, J. P., Morin, P., and Ruiz-Pino, D. P.: Temporal trends in nutrient ratios: chemical evidence of Mediterranean ecosystem changes driven by human activity, Deep-Sea Res. II, 49, $2007-$ 2016, 2002.

Boyd, P. W. and Harrison, P. J.: Phytoplankton dynamics in the NE subarctic Pacific, Deep-Sea Res. II, 46, 2405-2432, 1999.

Boyd, P. W., Sherry, N. D., Berges, J. A., Bishop, J. K. B., Calvert, S. E., Charette, M. A., Giovannoni, S. J., Goldblatt, R., Harrison, P. J., Moran, S. B., Roy, S., Soon, M., Strom, S., Thibault, D., Vergin, K. L., Whitney, F. A., and Wong, C. S.: Transformations of biogenic particulates from the pelagic to the deep ocean realm, Deep-Sea Res. II, 46, 2761-2792, 1999.

Boyd, P. W., Watson, A. J., Law, C. S., et al.: A mesoscale phytoplankton bloom in the polar Southern Ocean stimulated by iron fertilization, Nature, 407, 695-702, 2000.

Bowie, A. R., Whitworth, D. J., Achterberg, E. P., Mantoura, R. F. C., and Worsfold, P. J.: Biogeochemistry of Fe and other trace elements $(\mathrm{Al}, \mathrm{Co}, \mathrm{Ni})$ in the upper Atlantic Ocean, Deep-Sea Res. I, 49, 605-636, 2002.

Brock, T. D.: Calculating solar radiation for ecological studies, Ecol. Modell., 14, 1-19, 1981.

Broerse, A. T. C., Ziveri, P., van Hinte, J. E., and Honjo, S.: Coccolithophore export production, species composition, and coccolith$\mathrm{CaCO}_{3}$ fluxes in the NE Atlantic (34 degrees N 21 degrees W and 48 degrees N 21 degrees W), Deep Sea Res. II, 47, 1877-1905, 2000.

Bury, S. J., Boyd, P. W., Preston, T., Savidge, G., and Owens, N. J. P.: Size-fractionated primary production and nitrogen uptake during a North Atlantic phytoplankton bloom: implications for carbon export estimates, Deep-Sea Res. I, 48, 689-720, 2001.

Chavez, F. P., Ryan, J., Lluch-Cota, S. E., and Niquen, C. M.: From anchovies to sardines and back: multidecadal change in the $\mathrm{Pa}$ cific Ocean, Science, 299, 217-221, 2003

Denman, K. L. and Peña, M. A.: A coupled 1-D biological/physical model of the northeast subarctic Pacific Ocean with iron limitation, Deep-Sea Res. II, 46, 2877-2908, 1999.

Doney, S. C., Wallace, D. W. R., and Ducklow, H. W.: The North Atlantic carbon cycle: new perspectives from JGOFS and WOCE, in: The changing ocean carbon cycle, edited by: Hanson, R. B., Ducklow, H. W., and Field, J. G., 375-391, 2000.

Doney, S. C., Kleypas, J. A., Sarmiento, J. L., and Falkowski, P. G.: The US JGOFS Synthesis and Modeling Project - an introduction, Deep-Sea Res. II, 49, 1-20, 2002.

Dortch, Q.: The interaction between ammonium and nitrate uptake in phytoplankton, Mar. Ecol. Prog. Series, 61, 183-201, 1990.

Droop, M. R.: Some thoughts on nutrient limitation in algae, J. Phycol., 9, 264-272, 1973.

Dugdale, R. and Wilkerson, F.: Silicate regulation of new production in the equatorial Pacific upwelling, Nature, 391, 270-273, 1998.

Egge, J. K.: Are diatoms poor competitors at low phosphate concentrations?, J. Mar. Syst., 16, 191-198, 1998.

Engel, A., Zondervan, I., Aerts, K., et al.: Testing the direct effect of $\mathrm{CO}_{2}$ concentration on a bloom of the coccolithophorid Emiliania huxleyi in mesocosm experiments, Limnol. Oceanogr., 50, 493507, 2005.

Evans, G. T.: A framework for discussing seasonal succession and coexistence of phytoplankton species, Limnol. Oceanogr., 33, 1027-1036, 1988.

Evans, G. T. and Parslow, J. S.: A model of annual plankton cycles, Biol. Oceanogr., 3, 327-347, 1985.

Falkowski, P. G., Laws, E. A., Barber, R. T., and Murray, J. W.: Phytoplankton and their role in primary, new, and export production, in: Ocean biogeochemistry: the role of the ocean carbon cycle in global change, edited by: Fasham, M. J. R., Springer, 99-121, 2003.

Falkowski, P. G., Katz, M. E., Knoll, A. H., Quigg, A., Raven, J. A., Schofield, O., and Taylor, F. J. R.: The evolution of modern eukaryotic phytoplankton, Science, 305, 354-360, 2004. 
Fasham, M. J. R., Ducklow, H. W., and McKelvie, S. M.: A nitrogen-based model of plankton dynamics in the oceanic mixed layer, J. Mar. Res., 48, 591-639, 1990.

Fasham, M. J. R. and Evans, G. T.: Advances in ecosystem modeling within JGOFS, in: The changing ocean carbon cycle, edited by: Hanson, R. B., Ducklow, H. W., and Field, J. G., 417-446, 2000.

Fennel, K., Abbott, M. R., Spitz, Y. H., Richman, J. G., and Nelson, D. M.: Impacts of iron control on phytoplankton production in the modern and glacial Southern Ocean, Deep-Sea Res. II, 50, 833-851, 2003.

Field, C. B., Behrenfeld, M. J., Randerson, J. T., and Falkowski, P. G.: Primary production of the biosphere: integrating terrestrial and oceanic components, Science, 281, 237-240, 1998.

Freeland, H., Denman, K., Wong, C. S., Whitney, F., and Jacques, R.: Evidence of change in the winter mixed layer in the Northeast Pacific Ocean, Deep-Sea Res. I, 44, 2117-2129, 1997.

Frost, B. W. and Kishi, M. J.: Ecosystem dynamics in the eastern and western gyres of the Subarctic Pacific - a review of lower trophic level modelling, Prog. Oceanogr., 43, 317-333, 1999.

Fulton, E. A., Parslow, J. S., Smith, A. D. M., and Johnson, C. R.: Biogeochemical marine ecosystem models II: the effect of physiological detail on model performance, Ecological Modelling, 173, 371-406, 2004.

Gaul, W. and Antia, A. N.: Taxon-specific growth and selective microzooplankton grazing of phytoplankton in the Northeast Atlantic, J. Mar. Syst., 30, 241-261, 2001.

Gregg, W. W., Ginoux, P., Schopf, P. S., and Casey, N. W.: Phytoplankton and iron: validation of a global three-dimensional ocean biogeochemical model, Deep-Sea Res. II, 50, 3143-3169, 2003.

Grover, J. P.: Dynamics of competition among microalgae in variable environments: experimental tests of alternative models, Oikos, 62, 231-243, 1991.

Gruber, N., Keller, K., and Key, R. M.: What story is told by oceanic tracer concentrations?, Science, 290, 455-456, 2000.

Guillard, R. R. L., Kilham, P., and Jackson, T. A.: Kinetics of silicon-limited growth in the marine diatom Thalassiosira pseudonana Hassle and Heimdal (Cyclotella nana Hustedt), J. Phycol., 9, 233-237, 1973.

Hanson, R. B., Ducklow, H. W., and Field, J. G. (Eds.): The changing ocean carbon cycle: a midterm synthesis of the Joint Global Ocean Flux Study, Cambridge University Press, Cambridge, 2000.

Harrison, P. J., Boyd, P. W., Varela, D. E., Takeda, S., Shiomoto, A., and Odate, T.: Comparison of the factors controlling phytoplankton productivity in the NE and NW subarctic Pacific gyres, Prog. Oceanogr., 43, 205-234, 1999.

Harrison, P. J., Whitney, F. A., Tsuda, A., Saito, H., and Tadokoro, K.: Nutrient and plankton dynamics in the NE and NW gyres of the subarctic Pacific Ocean, J. Oceanogr., 60, 93-117, 2004.

Holligan, P. M. and Robertson, J. E.: Significance of carbonate formation for the ocean carbon cycle, Global Change Biol., 2, 8595, 1996.

Huisman, J. and Weissing, F. J.: Light-limited growth and competition for light in well-mixed aquatic environments: an elementary model, Ecology, 75, 507-520, 1994.

Hutchins, D. A. and Bruland, K. W.: Iron-limited diatom growth and Si:N uptake ratios in a coastal upwelling regime, Nature, 393, 561-564, 1998.
Iglesias-Rodrígues, M. D., Brown, C. W., Doney, S. C., Kleypas, J., Kolber, D., Kolber, Z., Hayes, P. K., and Falkowski, P. G.: Representing key phytoplankton functional groups in ocean carbon cycle models: coccolithophorids, Global Biogeochem. Cycles, 16, 47(1)-47(20), 2002.

Iida, T., Saitoh, S. I., Miyamura, T., Toratani, M., Fukushima, H., and Shiga, N.: Temporal and spatial variability of coccolithophore blooms in the eastern Bering Sea, 1998-2001, Prog. Oceanogr., 55, 165-175, 2002.

Johnson, K. S., Gordon, R. M., and Coale, K. H.: What controls dissolved iron concentrations in the world ocean?, Mar. Chem., 57, 137-161, 1997.

Joint, I. R., Pomroy, A., Savidge, G., and Boyd, P.: Size fractionated primary productivity in the North East Atlantic in Spring 1989, Deep-Sea Res. II, 40, 423-440, 1993.

Karl, D. M., Bidigare, R. R., and Letelier, R. M.: Long-term changes in plankton community structure and productivity in the North Pacific Subtropical Gyre: the domain shift hypothesis, Deep-Sea Res. II, 48, 1449-1470, 2001.

Kirk, J. T. O.: Light and photosynthesis in aquatic ecosystems, Cambridge University Press, Cambridge, 509 pp., 1994.

Kleypas, J. A. and Doney, S. C.: Nutrients, Chlorophyll, Primary Production and Related Biogeochemical Properties in the Ocean Mixed Layer - A Compilation of Data Collected at Nine JGOFS Sites, NCAR Technical Note NCAR/TN-447+STR, 55 pp., 2001.

Klausmeier, C. A., Litchman, E., and Levin, S. A.: Phytoplankton growth and stoichiometry under multiple nutrient limitation, Limnol. Oceanogr., 49, 1463-1470, 2004.

Lam, P. J., Tortell, P. D., and Morel, F. M. M.: Differential effects of iron additions on organic and inorganic carbon production by phytoplankton, Limnol. Oceanogr., 46, 1199-1202, 2001.

Langdon, C.: On the causes of interspecific differences in the growth-irradiance relationship for phytoplankton. II. A general review, J. Plankton Res., 10, 1291-1312, 1988.

Lochte, K., Ducklow, H. W., Fasham, M. J. R., and Stienen, C.: Plankton succession and carbon cycling at $47 \mathrm{~N} 20 \mathrm{~W}$ during the JGOFS North Atlantic Bloom experiment, Deep-Sea Res. II, 40, 91-114, 1993.

Longhurst, A. R.: Ecological geography of the sea, Academic Press, New York, 398 p., 1998.

Louanchi, F. and Najjar, R. G.: A global monthly climatology of phosphate, nitrate, and silicate in the upper ocean: springsummer export production and shallow remineralization, Global Biogeochem. Cycles, 14, 957-977, 2000.

Maldonado, M. T., Boyd, P. W., Strzepek, R., LaRoche, J. L., Waite, A., Croot, P. L., and Price, N. M.: Phytoplankton physiological responses to changing iron chemistry during a mesoscale Southern Ocean iron-enrichment, Limnol. Oceanogr., 46, 1802-1808, 2001.

Manabe, S., Stouffer, R. J., Spelman, M. J., and Bryan, K.: Transient responses of a coupled ocean-atmosphere model to gradual changes of atmospheric $\mathrm{CO}_{2}$. Part I: Annual mean response, J. Climate, 4, 785-818, 1991.

Marty, J.-C., Chiavérini, J., Pizay, M.-D., and Avril, B.: Seasonal and interannual dynamics of nutrients and phytoplankton pigments in the western Mediterranean Sea at the DYFAMED timeseries station (1991-1999), Deep-Sea Res. II, 49, 1965-1985, 2002 . 
Miller, J. R. and Russell, G. L.: Investigating the interactions among river flow, salinity, and sea ice using a global coupled atmosphere-ocean-ice model, Ann. Glaciol., 25, 121-126, 1997.

Montagnes, D. J. S., Berges, J. A., Harrison, P. J., and Taylor, F. J. R.: Estimating carbon, nitrogen, protein, and chlorophyll a from volume in marine phytoplankton, Limnol. Oceanogr., 39, 10441060, 1994.

Montagnes, D. J. S. and Lessard, E. J.: Population dynamics of the marine planktonic ciliate Strombidinopsis multiauris: its potential to control phytoplankton blooms, Aquat. Microb. Ecol., 20, 167-181, 1999.

Moore, J. K., Doney, S. C., Kleypas, J. A., Glover, D. M., and Fung, I. Y.: An intermediate complexity marine ecosystem model for the global domain, Deep-Sea Res. II, 49, 403-462, 2002.

Moore, J. K., Doney, S. C., and Lindsay, K.: Upper ocean ecosystem dynamics and iron cycling in a global three-dimensional model, Global Biogeochem. Cycles, 18, GB4028, 2004.

Muggli, D. L. and Harrison, P. J.: Effects of nitrogen source on the physiology and metal nutrition of Emiliania huxleyi grown under different iron and light conditions, Mar. Ecol. Prog. Ser., 130, 255-267, 1996.

Napp, J. M. and Hunt, G. L.: Anomalous conditions in the southeastern Bering Sea 1997: linkages among climate, weather, ocean, and biology, Fisheries Oceanogr., 10, 61-68, 2001.

Orr, J. C., Fabry, V. J., Aumont, O., et al.: Anthropogenic ocean acidification over the twenty-first century and its impact on calcifying organisms, Nature, 437, 681-686, 2005.

Pahlow, M. and Riebesell, U.: Temporal trends in deep ocean Redfield ratios, Science, 287, 831-833, 2000.

Peña, M. A.: Modelling the response of the planktonic food web to iron fertilization and warming in the NE subarctic Pacific, Prog. Oceanogr., 57, 453-479, 2003.

Platt, T., Fuentes-Yaco, C., and Frank, K. T.: Spring algal bloom and larval fish survival, Nature, 423, 398-399, 2003.

Press, W. H., Teukolsky, S. A., Vetterling, W. T., and Flannery, B. P.: Numerical recipes in FORTRAN, 2nd ed., Cambridge University Press, 1992.

Quigg, A., Finkel, Z. V., Irwin, A. J., Rosenthal, Y., Ho, T.-Y., Reinfelder, J. R., Schofield, O., Morel, F. M. M., and Falkowski, P. G.: The evolutionary inheritance of elemental stoichiometry in marine phytoplankton, Nature, 425, 291-294, 2003.

Rappé, M. S., Suzuki, M. T., Vergin, K. L., and Giovannoni, S. J.: Phylogenetic diversity of ultraplankton plastid small-subunit rRNA genes recovered in environmental nucleic acid samples from the Pacific and Atlantic coasts of the United States, Appl. Environ. Microbiol., 64, 294-303, 1998.

Richardson, K., Beardall, J., and Raven, J. A.: Adaptation of unicellular algae to irradiance: an analysis of strategies, New Phytologist, 93, 157-191, 1983.

Ridgwell, A. J.: Dust in the Earth system: the biogeochemical linking of land, air and sea, Phil. Trans. R. Soc. Lond. A, 360, 29052924, 2002.
Riegman, R., Stolte, W., Noordeloos, A. A. M., and Slezak, D.: Nutrient uptake and alkaline phosphatase (EC 3:1:3:1) activity of Emiliania huxleyi (Prymnesiophyceae) during growth under $\mathrm{N}$ and $\mathrm{P}$ limitation in continuous cultures, J. Phycol., 36, 87-96, 2000.

Russell, G. L., Miller, J. R., and Rind, D.: A coupled atmosphereocean model for transient climate change studies, Atmos.-Ocean, 33, 683-730, 1995.

Sarmiento, J. L., Hughes, T. M. C., Stouffer, R. J., and Manabe, S.: Simulated response of the ocean carbon cycle to anthropogenic climate warming, Nature, 393, 245-249, 1998.

Savidge, G., Boyd, P., Pomroy, A., Harbour, D., and Joint, I.: Phytoplankton production and biomass estimates in the northeast Atlantic Ocean, May-June 1990, Deep-Sea Res. I, 42, 599-617, 1995.

Smayda, T. J.: Harmful algal blooms: Their ecophysiology and general relevance to phytoplankton blooms in the sea, Limnol. Oceanogr., 42, 1137-1153, 1997.

Smetacek, V.: Diatoms and the ocean carbon cycle, Protist, 150, 25-32, 1999.

Staal, M., Meysman, F. J. R., and Stal, L. J.: Temperature excludes $\mathrm{N}_{2}$-fixing heterocystous cyanobacteria in the tropical oceans, Nature, 425, 504-507, 2003.

Sunda, W. G. and Huntsman, S. A.: Iron uptake and growth limitation in oceanic and coastal phytoplankton, Mar. Chem., 50, 189-206, 1995.

Sverdrup, H. U.: On conditions for the vernal blooming of phytoplankton, J. Cons. Perm. Int. Explor. Mer, 18, 287-295, 1953.

Tilman, G. D.: Resource competition and community structure, Princeton University Press, Princeton, NJ, 1982.

Tyrrell, T., Holligan, P., and Mobley, C.: Optical impacts of oceanic coccolithophore blooms, J. Geophys. Res., 104, 3223-3242, 1999.

Tsuda, A., Takeda, S., Saito, H., et al.: A mesoscale iron enrichment in the Western Subarctic Pacific induces a large centric diatom bloom, Science, 300, 958-961, 2003.

Van der Staay, S. Y. M., De Wachter, R., and Vaulot, D.: Oceanic 18S rDNA sequences from picoplankton reveal unsuspected eukaryotic diversity, Nature, 409, 607-610, 2001.

Varela, D. E. and Harrison, P. J.: Seasonal variability in nitrogenous nutrition of phytoplankton assemblages in the northeastern subarctic Pacific Ocean, Deep-Sea Res. II, 46, 2505-2538, 1999.

Weeks, A., Conte, M. H., Harris, R. P., et al.: The physical and chemical environment and changes in community structure associated with bloom evolution - the joint global flux study northAtlantic bloom experiment, Deep-Sea Res. II, 40, 347-368, 1993.

Woody, C., Shih, E., Miller, J., Royer, T., Atkinson, L., and Moody, R.: Salinity measurements in the coastal ocean, Workshop review, September 1998, CCPO Technical Report, 99-01, 1999.

Wroblewski, J. S.: A model of phytoplankton bloom formation during variable Oregon upwelling, J. Mar. Res., 35, 357-394, 1977. 